\title{
Paving the Way for Circular Supply Chains: Conceptualization of a Circular Supply Chain Maturity Framework
}

\section{OPEN ACCESS}

Edited by:

Simone Sehnem,

University of West of Santa

Catarina, Brazil

Reviewed by:

Konrad Prandecki,

Institute of Agricultural and Food

Economics, Poland

Davide Settembre Blundo,

Rey Juan Carlos University, Spain

*Correspondence:

Laura Montag

laura.montag@rub.de

Specialty section:

This article was submitted to

Circular Economy,

a section of the journal

Frontiers in Sustainability

Received: 23 September 2021 Accepted: 04 November 2021 Published: 29 November 2021

Citation:

Montag L, Klünder T and Steven M (2021) Paving the Way for Circular

Supply Chains: Conceptualization of a

Circular Supply Chain Maturity

Framework. Front. Sustain. 2:781978.

doi: 10.3389/frsus.2021.781978

\section{Laura Montag*, Timo Klünder and Marion Steven \\ Chair of Production Management, Faculty of Management and Economics, Ruhr University Bochum, Bochum, Germany}

The European Green Deal aims to make Europe climate neutral by 2050. According to this ambitious plan, $50 \%$ of greenhouse gas emissions are to be saved through a wide implementation of a circular economy. With supply chains responsible for four-fifths of greenhouse gas emissions, their role in the transition from linearity to a circular economy, and thus in the successful implementation of circular systems, is critical and requires the attention of academia, policymakers, and practitioners. Maturity models are suitable for monitoring, assessing, and evaluating the transformation process and determining the status quo of a supply chain. However, as the implementation of circular supply chains is still in its infancy, circular maturity frameworks at the supply chain level are not available yet. Therefore, the purpose of this study is to conceptualize a framework for analyzing the maturity level of circular economy adoption in the supply chain context. From an extensive and systematic literature review of overall 1,372 articles on supply chains, circular economy and maturity the following findings can be drawn: (i) circular economy and circular supply chains are massively growing research streams; (ii) the link between circular economy, supply chains and maturity assessment is so far missing; (iii) three constructs (organization, products, processes) characterize and influence circular supply chain maturity; (iv) a 3-layered maturity grid covering six archetypal elements of the circular economy enables the assessment of a circular supply chain maturity. The developed circular supply chain maturity framework paves the way for circular economy adoption at supply chain level by understanding current level of circular maturity and thus supporting the circular economy implementation process at supply chain level.

Keywords: circular supply chain, circular maturity assessment, circular economy, systematic literature review, maturity assessment

\section{INTRODUCTION}

The Intergovernmental Panel on Climate Change alerts in its Sixth Assessment Report of a significantly faster global warming than previously assumed (IPCC, 2021). At current trends, the earth would already warm by $1.5^{\circ} \mathrm{C}$ around 2030 compared to the pre-industrial era-and thus 10 years earlier than forecasted in 2018. The IPCC Sixth Assessment Report draws the conclusion that global surface temperature will continue to rise until at least mid-century. Global warming of $1.5^{\circ} \mathrm{C}$ will be exceeded during the twenty-first century unless drastic reductions in $\mathrm{CO}_{2}$ and other 
greenhouse gas emissions can be achieved in the coming decades. $\mathrm{CO}_{2}$ emissions do not only occur in the last production step but affect all upstream and downstream areas of production. Supply chains account for around $80 \%$ of $\mathrm{CO}_{2}$ emissions, depending on the sector (World Economic Forum, 2021). Therefore, it is crucial to focus not on individual companies but on the entire supply chain to counteract dramatic global warming and to achieve sustainability goals.

A plethora of managerial concepts, technical practices, and legislative proposals have been suggested to address these problems (Blasi et al., 2021). The straight-line model of resource consumption based on the "take-make-waste" approach appears to be inadequate for battling climate change (Homrich et al., 2018). The circular economy concept has lately gained momentum from policy makers, businesses and NGOs as an economic system that replaces this straight-line model of production and consumption by decoupling economic growth from resource depletion and environmental degradation (Murray et al., 2017). Despite the fact that the circular economy has received increasing visibility since 2015 , it can be traced back to the work of Pearce et al. (1990), which was inspired by Boulding (1966). Boulding (1966) noted that the earth's assimilative capacity is limited and that a balance between economy and environment must be sought. Raw material consumption is closely correlated with greenhouse gas emissions, as increasing consumption of new products generates $\mathrm{CO}_{2}$ emissions for the extraction, processing and transport of raw materials along the value chain (Umweltbundesamt, 2018). In achieving the circular economy, the value of products and materials is preserved for as long as possible. Waste and resource consumption are minimized, and products are reused at their end of life. This results in major economic benefits for companies, including increased innovation, financial growth, and job creation (Pearce et al., 1990; Geng and Doberstein, 2008).

While $16 \%$ of U.S. companies already use circular economy principles, $62 \%$ plan to do so (ING, 2018). Politically, the concept of the circular economy is defined within the framework of the European Green Deal as one of the central fields of action on the way to climate neutrality by 2050. Since the implementation of the circular economy is a long, complex, and cross-company process, a tool is needed to identify reached milestones and potential deficits. Therefore, the research streams depicted in Figure $\mathbf{1}$ are considered first separately and then in an integrated approach to conceptualize the maturity of circularity in supply chains. The body of knowledge on supply chains, circular economy and maturity gets examined descriptively and thematically to conceptualize circular supply chain maturity. The proposed framework aims to understand and analyze the current level of circular economy adoption in the supply chain context.

This paper is structured as follows: Section Theoretical Background provides the theoretical background on supply chains (subsection Supply Chain's Contribution to Sustainability), circular economy (subsection Circular Economy Concept), and maturity assessment (subsection Maturity Assessment). Details on the underlying research methodology are presented in section Research Methodology by first elaborating research scopes and objectives and then explaining

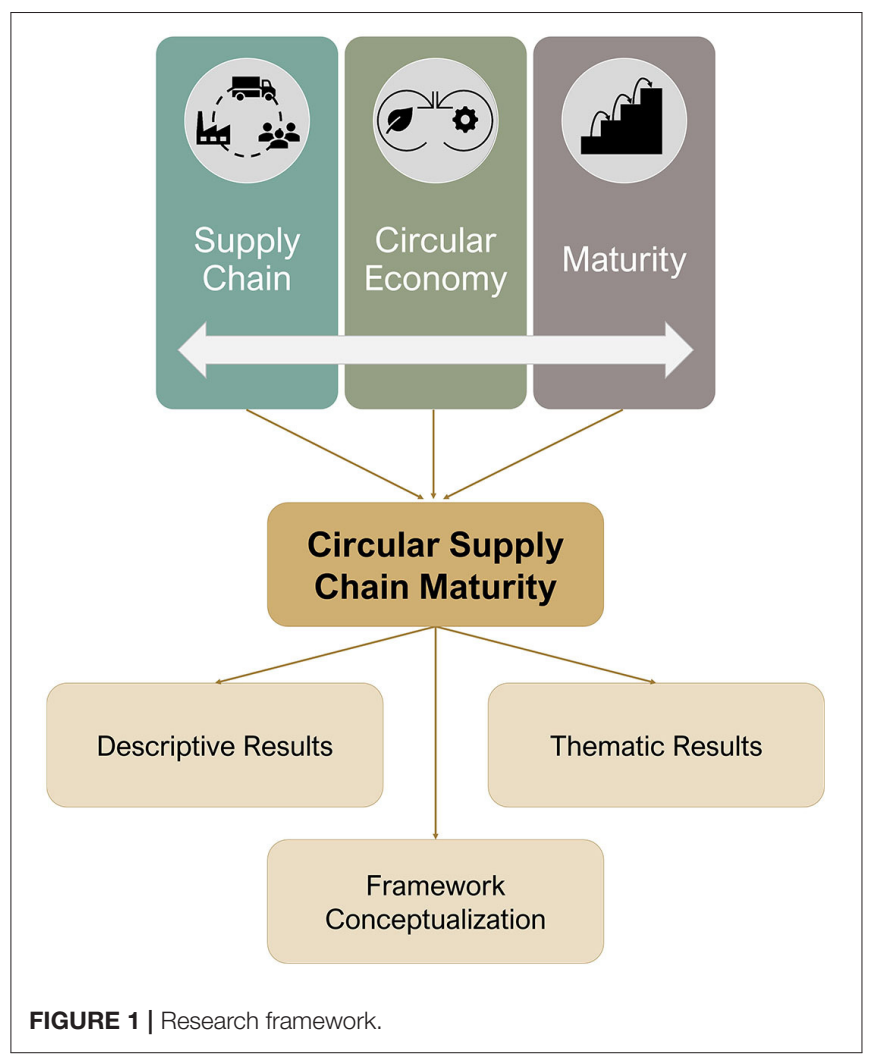

the research design. Section Research Results includes the results obtained from the systematic literature review (SLR), divided into descriptive and thematic results. The theoretical framework for circular supply chain maturity is developed and presented in Section Development of a Maturity Framework in the Circular Supply Chain Context. Finally, in Section Conclusion, Limitations and Future Research Opportunities, conclusions, future research opportunities and limitations are discussed.

\section{THEORETICAL BACKGROUND \\ Supply Chain's Contribution to Sustainability}

The increase of global sourcing in the 1980s led to the development of several definitions and concepts of supply chains and supply chain management (Angelis and Miemczyk, 2018). Mangan et al. (2012) describe supply chains as a “[...] network of organizations that are involved, through upstream and downstream linkages, in the different processes and activities that produce value in the form of products and services in the hands of the ultimate customer [...]" (Mangan et al., 2012). The constituent elements of this fundamental definition of a supply chain have since been subject to controversial discussions regarding the nature of the network, the existence of a focal firm, the number of upstream and downstream firms to be considered, or the formal and substantive goals of these networks (Stevenson and Spring, 2007). While minimizing costs and maximizing throughput are the undisputed formal objectives 
of supply chains, numerous substantive objectives exist. While in the past robust, lean, or flexible supply chains were the objective, nowadays, in the light of increasingly interdependent economic, ecological, and social crises, sustainable supply chains are the objective.

Sustainable development is defined as a "[...] development that meets the needs of the present without compromising the ability of future generations to meet their own needs [...]" (WCED, 1987). Thus, sustainable supply chain management represents the management of material, information and capital flows along the supply chain considering goals from all three dimensions of sustainable development, i.e., economic, environmental, and social (Seuring and Müller, 2008).

There is an extensive debate regarding the prioritization or hierarchization of these three dimensions of sustainability. While some economists subordinate the ecological and social dimensions to the economic dimension, others strive for an equal weighting as a triple bottom line. However, an integrated view and the development of frameworks or measurement tools that take all three dimensions equally and simultaneously into account fail in most cases. For this reason, and since the environmental challenges are the most urgent, illustrated by the current status report of the IPCC, this study focuses on the environmental dimension, using the concept of circular economy.

Although the circular economy primarily has direct effects in the environmental dimension of sustainability, it also has subsequent consequences in the economic and social dimensions, ultimately leading to holistic sustainable development (see Figure 2). The utilization of by products and waste generates new value streams the economical dimension and creates the productive potential for the re-shoring of jobs. By gains in resource efficiency raw material and energy costs can be cut, increasing the competitiveness of supply chains. The reduction of waste and pollution directly cuts regulative costs as well as disposal costs. Moreover, the supply chain is allowed to compete in all global markets. The protection of the environment increases the value of nature in the social dimension. Reducing or eliminating the use of virgin materials reduces dependence on suppliers ensuring a noninterrupted operational service. In the social dimension, wins are achieved by limiting the exploitation of labor in developing and emerging countries when extracting virgin materials. The effects within and between the three pillars of sustainability are complex. This further motivates a focus on just one dimension.

In order to achieve the long-term temperature goal set out in Article 2 of the Paris Agreement, the 195 parties aim to "[...] reach global peaking of greenhouse gas emissions as soon as possible, [...] to achieve a balance between anthropogenic emissions by sources and removals by sinks of greenhouse gases in the second half of this century [...]" (UN, 2015). This goal is called climate neutrality. The European Green Deal aims to make Europe climate neutral by 2050 (Siddi, 2020).

In 2019, Germany emitted a total of approximately 439 million metric tons $(\mathrm{mt})$ of greenhouse gases in carbon dioxide $\left(\mathrm{CO}_{2}\right)$ equivalents. Since supply chains account for about four-fifths of all carbon emissions (World Economic Forum, 2021), they need to be focused on climate neutrality. Achieving a balance between carbon emissions and the absorption of carbon from the atmosphere in carbon sinks can only be achieved by two pathways: the massive development of carbon sinks and/or the massive reduction of carbon emissions:

- Afforestation is the typical way to develop carbon sinks. Per year, one beech tree, the most common deciduous tree in Europe, sequesters about $12.5 \mathrm{~kg}$ of $\mathrm{CO}_{2}$. Accordingly, 80 trees would have to be planted to offset one ton of $\mathrm{CO}_{2}$ each year. To create a carbon sink for four-fifths of the carbon dioxide emitted in Germany in 2019 (351.2 mt), 28,096 million beech trees would have to be planted. Since approximately 150 beech trees can be planted on one hectare, this would require 187 million hectares. This corresponds to $11 \%$ of the total surface area of Germany (1,606 million hectares). With forest area accounting for about $30 \%$ of Germany's total surface area, creating classic carbon sinks to achieve climate neutrality is unfeasible.

- A massive reduction in $\mathrm{CO}_{2}$ emissions is therefore required (in addition). This is a more promising approach, as a study from the automotive industry shows. The introduction of circular economy methods in combination with the rapidly growing electrification in the automotive industry have the potential to reduce $\mathrm{CO}_{2}$ emissions by up to $75 \%$ by 2030 , according by a study from the World Economic Forum (2021). While the use of emission-saving technologies is easily observable and statistically recorded, the implementation of the principles of a circular economy in supply chains is not easily observable. Moreover, circular economy offers supply chains resource efficiency gains, which increase their competitiveness, new value streams through utilization of by-products and waste, an avoidance of regulative costs as a result of environmental pollution, an increase of brand reputation and a reduction of risks through the exclusion of globally distributed resources that are volatile in price (Masi et al., 2017).

A massive reduction in $\mathrm{CO}_{2}$ emissions by implementing the circular economy in supply chains is thus the most promising approach to set up environmentally sustainable supply chains and achieve the $1.5^{\circ} \mathrm{C}$ target.

\section{Circular Economy Concept}

Over the past decade, the circular economy concept rapidly evolved-from a modest recycling-related theory toward an independent economic system, offering great potential for balancing economic, environmental, and social needs (Stahel, 2019). A quick look at the sheer volume of scholarly publications illustrates its position in academic research: From 2010 to 2014, the search term "circular economy" returned only about 150-170 results within the Web of Science (WoS) database, a relatively constant trend. However, the following 5 years saw a significant rise in publications. Each year the numbers increased considerably, reaching their peak-at least so far-in 2020 with over 3,300 publications. Within 10 years, the research field (only according to WoS figures) has thus experienced an increase of over $2,000 \%$. So, there is no question that the circular economy research field expands at an accelerated rate and thus is 


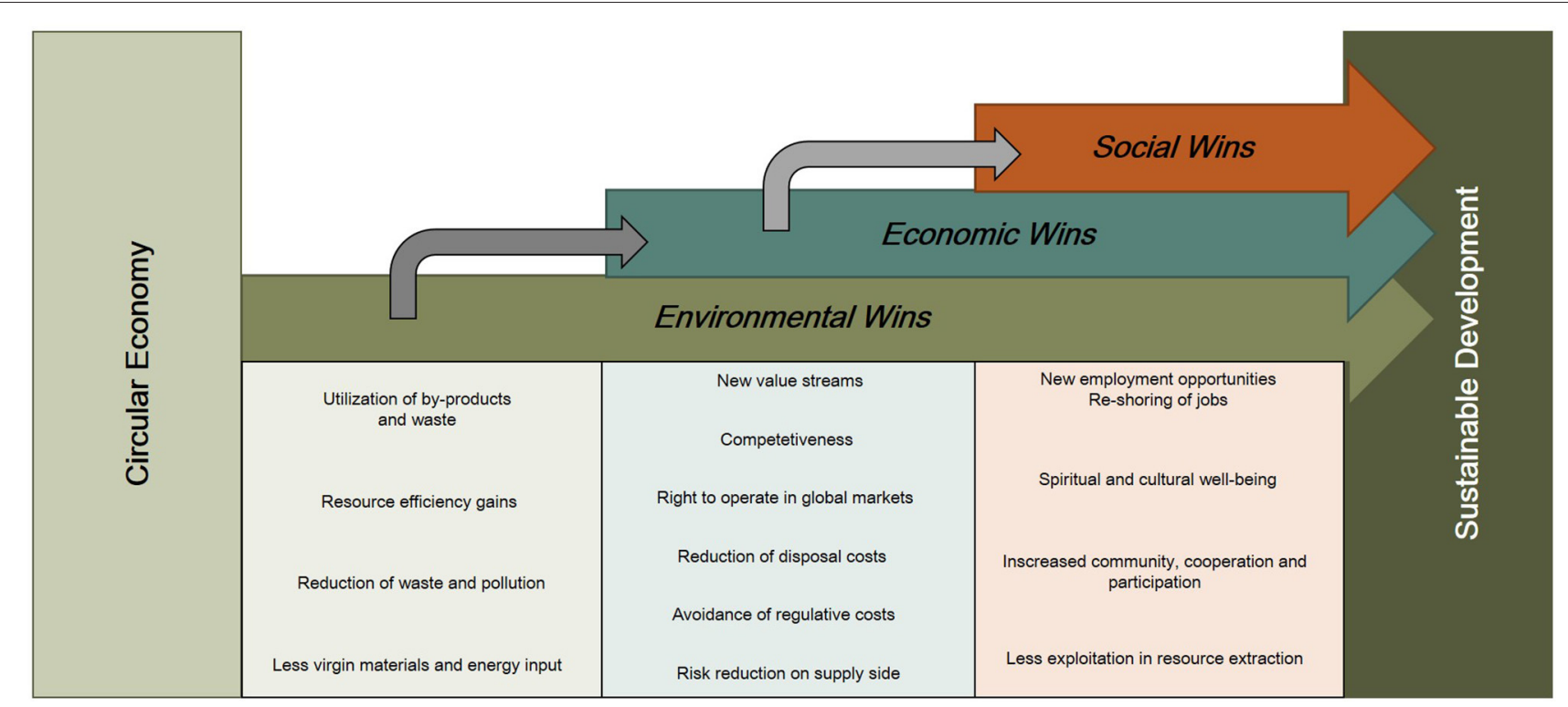

FIGURE 2 | Circular economy's contribution to sustainable development (in accordance with Korhonen et al., 2018).

currently one of the most discussed topics among economists and sustainability scientists (Geisendorf and Pietrulla, 2018; Merli et al., 2018; Sehnem et al., 2021).

A non-negligible problem arising from this rapid development is the lack of transparency and agreement about the current understanding of the circular economy concept, which hinders its further progress, in particular, the successful transition from linearity to circularity (Kirchherr et al., 2017; Prieto-Sandoval et al., 2018). There is a consensus in the scientific community that the circular economy is the better alternative to the traditional, linear economy with its "take-make-waste" approach (Homrich et al., 2018). Yet there is widespread division about which strategies, practices, and most importantly which goals belong to the core elements of the circular economy. In particular, its relationship and contribution to sustainable development is a highly debated issue (Sauvé et al., 2016; Geissdoerfer et al., 2017; Korhonen et al., 2018). Two of the three most frequently cited papers (in the WoS database) deliver definitions on the circular economy which diverge significantly. While Geissdoerfer et al. (2017) focus more on the elements of regeneration, slowing, closing, and narrowing resource loops as well as the implementation of R-imperatives, Kirchherr et al. (2017) strongly emphasize-after an intensive analysis of 114 different definitions - that the circular economy holistically aims to accomplish sustainable development at all levels to benefit the current as well as all future generations.

In order to realize the vision and potential of the circular economy and enable circular business models, it is essential to integrate the appropriate strategies, practices, and goals into supply chain management (Homrich et al., 2018; Farooque et al., 2019). The feasible implementation of the circular economy depends on how successful a holistic rethinking of traditional strategic, tactical, and operational processes along the supply

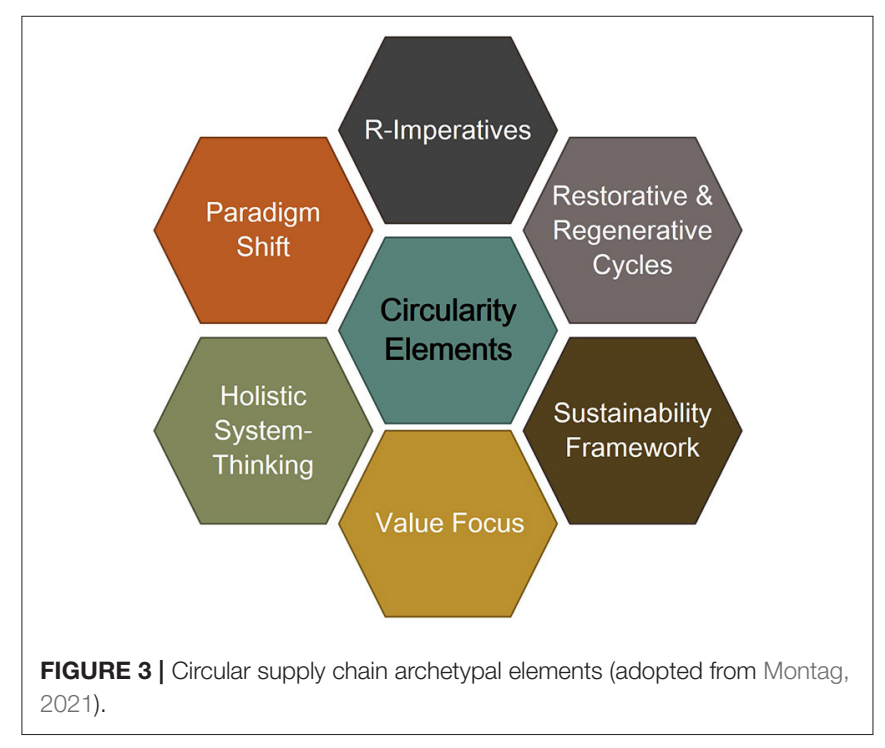

chain is carried out (Homrich et al., 2018). Based on a previous comprehensive study on the circular supply chain management research field (Montag, 2021), we propose six archetypal elements to provide conceptual transparency for the analysis and discussion that follows in the subsequent chapters. These archetypal elements are depicted in Figure 3 and include: (1) R-Imperatives, (2) Restorative and Regenerative Cycles, (3) Sustainability Framework, (4) Value Priorities, (5) Holistic System-Thinking, and (6) Paradigm Shift.

The implementation of a waste management strategy is a key operational principle of the circular economy (Kirchherr et al., 2017). The so called "re-activities" or R-imperatives are 
widely used within the literature, though with varying quantities, meaning and hierarchies of the activities (Reike et al., 2018). The proposed R-frameworks found in scientific research range from 3Rs to 10Rs (Reike et al., 2018). A very nuanced one is the framework proposed by Potting et al. (2017). Their 10Rframework is structured into three groups, from highest level of circularity to lowest: smart product use and manufacture (refuse, rethink, reduce), extending lifespan of product and its parts (reuse, repair, refurbish, remanufacture, repurpose), and useful application of materials (recycle, recover).

Another characteristic that is frequently found in the literature, but whose understanding and significance in context of the circular economy is still debated, is restorative and regenerative cycles. The Ellen MacArthur Foundation-as a flagship organization promoting the circular economyclaims that a "circular economy is one that is restorative and regenerative by design" (Ellen MacArthur Foundation, 2015). However, literature on circular economy indicates that the exact meaning of these terms are rarely defined or in detail explained (Morseletto, 2020). Within restorative cycles, the goal is that discarded technical (non-organic) products and materials become technical nutrients through the application of R-activities, within regenerative cycles, discarded organic products become biological nutrients as natural capital (Ellen MacArthur Foundation, 2017). In both cycles products and materials can flow in open- or closed-loops, either flowing reverse within one supply chain or cascading forward toward other supply chains (Batista et al., 2018).

As mentioned earlier, the relationship between circular economy and sustainability is also being discussed in the scientific community. While some perceive the circular economy as a concept that is fully neglecting the social dimension of sustainable development, other understand it as a concept that contributes to all three dimensions of sustainability, thus aiming for economic wins (e.g., reduced material and energy costs), environmental wins (e.g., reduced emissions) and social wins (e.g., in terms of new employment opportunities) (Korhonen et al., 2018). In the context of this study, the circular economy is understood as a concept that clearly focuses on the environmental dimension but thereby also promotes positive changes at the economic and social level.

A fourth archetypal characteristic of the circular economy and the circular supply chain concept is the focus on values. Especially within circular business models, most conceptualizations follow a value logic framework (Richardson, 2008), i.e., value proposition, value creation and delivery as well as value capture (Geissdoerfer et al., 2020). Circular value proposition corresponds with offering value to customers through products and services. This value lies for example in used, repaired, remanufactured, refurbished, or recycled products and materials or in long-lasting, upgradable products (Lüdeke-Freund et al., 2018). Circular value can be created and delivered through key circular activities such as the implementation of R-processes, cycling and cascading (Ellen MacArthur Foundation, 2013). Circular value capture corresponds with the economic, environmental, and social costs reduction and additional revenue streams that are generated through the value creation (Geissdoerfer et al., 2020). These could be savings from reduced costs due to the input of recycled material, increased margins due to reusing products or additional revenues from residual values (Bocken et al., 2016).

Closely related to the focus on values is the holistic systemthinking which is key for understanding the complex links and interconnectedness in a circular production and consumption system. For a supply chain to transform from strictly linear to circular, various challenges along the different lifecycle phases and among different supply chain actors arise, requiring a systemic and holistic thinking (Bressanelli et al., 2018). In particular, the inclusion of the consumer perspective is critical to the success of a transformation from linear to circular systems, as it implies acceptance of used products or recycled materials, active participation in take-back systems or upcycling, and an overall higher level of responsibility (Govindan and Hasanagic, 2018).

Finally, the last characteristic of a circular system is the paradigm shift. A holistic and successfully applied circular economy or circular supply chain requires profound economic, environmental, and societal transformations that are equivalent to a paradigm shift in the production and consumption system (Loiseau et al., 2016). This paradigm shift involves structural changes at the strategic level to facilitate the implementation of circular strategies at the tactical and operational level.

\section{Maturity Assessment}

Maturity describes the state of being complete, ideal, perfect, or ready and therefore implies an evolutionary advancement (Stevenson, 2010). Readiness is often used as a synonymous term, although maturity and readiness differ slightly in their exact meaning. Readiness indicates that an organization is prepared to respond to future and uncertain change requirements. Thus, maturity assessment captures the as-is state during the maturing process, whereas readiness is required before engaging the maturing process (Çinar et al., 2021). In addition to that, the concept of maturity requires differentiation from the concept of diffusion. Diffusion focuses on the conditions that determine the likelihood of adopting an idea or concept. Since supply chains are the source of sustainability issues and the circular economy does not passively diffuse through the actors of a supply chain over time like technologies do, but requires action, the concept of maturity is preferred over the concept of diffusion. Moreover, as most companies and supply chains are already in the stage of incorporating the principles and methods of the circular economy, a circular maturity assessment framework becomes more and more desirable for companies aiming to transform from linear to circular.

A maturity model is often not understood as a formalized concept, so many authors refrain from a definition (Wendler, 2012; Correia et al., 2017). However, to systematize the studies extracted in a structured literature analysis and to develop a well-founded framework for maturity assessment, a definition as well as the determination of the elements constituting a maturity model is crucial. According to Pullen (2007) a maturity model represents a structured collection of elements that describe the characteristics of effective processes at different stages of development. Correia et al. (2017) identify the scope of maturity, 
the typology of assessment and the components of the maturity framework as constituent elements:

- Maturity models assess the maturity of an entity on a more or less comprehensive set of criteria (Bruin et al., 2005). The scope determines the extent to which the model is applied in its domain. The domain of this study is supply chains, so to classify the literature in scope, a distinction is made between product, process, company, and network maturity.

- The typology indicates the individual elements' arrangement of the maturity model. In a (Likert-like) questionnaire, the individual elements of the maturity model are presented in an unordered or ordered set of questions. The respondent classifies the supply chain on a scale from 0 or $1-n$. The maturity grid strives for a hierarchical decomposition of the problem. The resulting subproblems can then be presented to the respondent for evaluation. The determination of this structure is usually based on plausibility and qualitative studies. These types were considered as less complex than structured models. Fraser et al. (2002) stresses that simpler structures are preferred for an application-oriented maturity assessment. Structured models represent a formal and complex structure. The relationships between individual elements are not based on plausible and qualitative studies, but are mathematically modeled (Correia et al., 2017).

- The constituent element components consists of the number of maturity levels, the naming of the descriptors, and an indication of the level of detail in the characterization of these levels. Fraser et al. (2002) emphasize that the number of levels used is arbitrary. It would be more a matter of creating a meaningful descriptor for each level and formulating a level description that sufficiently distinguishes the individual levels clearly from one another.

\section{RESEARCH METHODOLOGY \\ Research Scope and Objectives}

The objective of this study is to develop a conceptual framework for assessing the maturity level of circular economy adoption at supply chain level. The later proposed framework aims at understanding what circular maturity means and supports the gradual transformation from linearity toward circularity. Since research on circular supply chain maturity is currently lacking in the literature, this research aims to close this gap by identifying how the circular supply chain is characterized as a concept and following that examining how circular maturity within the supply chain context can be understood and evaluated. The leading research question that guides through this paper can therefore be formulated as follows:

$R Q:$ How can the maturity of circular economy implementation be conceptualized at supply chain level?

In order to achieve the research objective described above and provide an adequate answer to the proposed main research question, three more detailed and narrowly focused research questions were formulated. The following sections within this paper focus on systematically answering the subsequent research questions:

- RQ1: What is the body of knowledge on maturity assessment in the context of the (circular) supply chain and thus contributes to the understanding of circular maturity?

- RQ2: What are elements, components and scopes that determine and influence the maturity of a circular supply chain?

- RQ3: What dimensions and maturity levels are required to holistically conceptualize and evaluate the circular maturity in the supply chain context?

\section{Research Design}

To address the formulated RQs, a SLR was carried out. According to Tranfield et al. (2003), the goal of SLRs is to provide reliable knowledge for a research field and its sub-fields through the theoretical synthesis of a series of studies. The SLR methodology involves first locating existing studies, selecting, and evaluating the underlying contributions to the research area, and then analyzing and synthesizing the information and data found so that conclusions can be drawn about the reported findings (Denyer and Tranfield, 2009). Through the SLR's in-depth exploration of the underlying research field both descriptive (e.g., the analysis of publications years, sources, or research focus) and thematic results (e.g., the identification of definitions, conceptualizations, or research streams) can be obtained. The SLR as a methodology is therefore well-suited to ensure that each research question is answered appropriately and comprehensively.

The SLR research design in this study is based on Denyer and Tranfield's approach. Their review process includes five steps: (1) question formulation, (2) locating studies, (3) study selection and evaluation, (4) analysis, and synthesis and (5) reporting and using the results. To reconcile these steps with the research scope and objective of this study, some adaptions were made. We propose the following three research phases in correspondence to the earlier formulated research questions:

- Phase 1-Locating and Selecting Studies-RQ1

- Phase 2-Analyzing and Synthesizing-RQ2

- Phase 3-Reporting and Using of Results-RQ3.

Figure 4 presents a methodology flowchart, depicting the three phases of the SLR and the relevant output for each phase. In the subsequent sections, the proposed phases will be described in more detail.

\section{Phase 1-Locating and Selecting Studies}

In order to conceptualize a framework for assessing the maturity of circular supply chains, this study aims to combine several research directions. As described and motivated in the introduction, the three research streams-supply chains, circular economy, and maturity assessment-are brought together to locate studies that contribute to the understanding of circular maturity. Overall, we applied four search strings to capture all relevant combinations for our study. We executed the search 


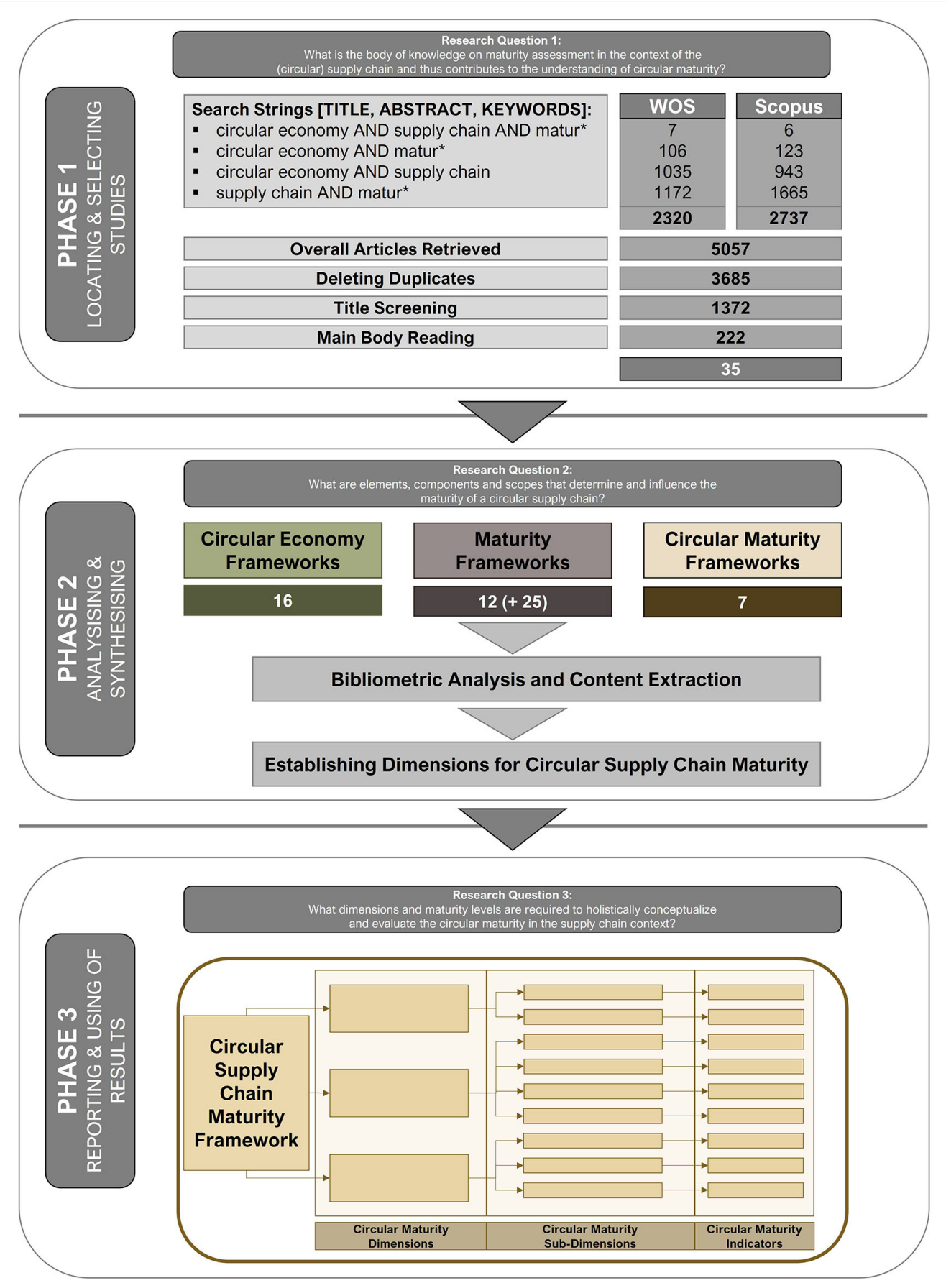

FIGURE 4 | Research methodology.

in June 2021 in the two most used databases within scientific community, WoS as well as Scopus, to mitigate the risk of missing essential studies for circular maturity (Piwowar-Sulej et al., 2021). The scope of this search included (peer-reviewed) journal articles and conference proceedings published in English. While the former were included to consider cutting-edge research studies published in ranked journals that decidedly address the questions formulated, the latter were included to consider very recent but less elaborated ideas that concern (circular) supply chain maturity.

The first search string applied to titles, abstracts, and keywords was "circular economy" AND "supply chain" AND "matur*” and yielded 7 studies in the WoS database and 6 in the Scopus database. This clearly indicates a lack of literature on circular 
supply chain maturity and justifies an investigation of the identified research gap. The second search string aimed at finding studies that focus on maturity assessment within the circular economy context (strings "circular economy" AND "matur*”). With this search we intended to deliver an understanding of maturity assessment in the context of circular economy. This query yielded 106 studies in WoS and 123 studies in Scopus. For our third search we applied the terms "circular economy" AND "supply chain," concentrating here on studies that focus on the integration of circular principles into supply chain management to gain insights on which dimensions are of importance in the transition from linear to circular supply chains. This search retrieved 1.035 studies in WoS and 943 in Scopus. Lastly, the fourth search applied the terms "supply chain" AND "matur*” to locate the widest set of studies, focusing on maturity assessment in the whole supply chain research stream. This search resulted in a total of 1.172 studies in WoS and 1.665 studies in Scopus.

Overall, adding up the results from four different searches in two databases, 5.057 studies were found. After deleting duplicates (3.685 studies), a set of 1.372 studies remained for further selection. To do so, the titles and keywords of all 1.372 studies in the set were screened and articles that could contribute to the conceptualization of circular supply chain maturity were selected for an in-depth text analysis. Accordingly, the set was shortened by 1.150 studies. Thus, 222 studies were examined in detail through main body reading. Finally, after study selection and evaluation, a set of 35 studies remained. The central selection criterion throughout the whole screening process was the consistency with the research purpose, i.e., identifying studies that are focusing on maturity of the (circular) supply chain or conduct broader maturity assessment in the context of circular economy or supply chain, as these studies enable the conceptualization of a maturity framework for the circular supply chain.

\section{Phase 2-Analysis and Synthesis}

Within phase 2 of the SLR, the set of 35 articles was thoroughly studied to find information on circular supply chains, circular economy maturity, and maturity assessment in the general supply chain context. Thus, the aim was to understand what aspects indicate the maturity of circular supply chains and to create a generic framework, assessing maturity appropriately.

The full set of 35 studies was classified according to their thematic contribution. Depending on the search queries, the following three groups emerged (number of studies within this group): circular economy frameworks (16), maturity frameworks (12) and circular economy maturity frameworks (7). All 35 studies were first classified according to year of publication, their research type and research purpose as well as their main findings. Table 1 in subsection Descriptive Results depicts this information in detail. Second, the circular economy related studies (hence the circular economy frameworks and circular maturity frameworks) were classified according to the in subsection Circular Economy Concept proposed circular economy archetypal elements: R-imperatives, restorative and regenerative cycle, sustainability framework, value creation, holistic system-thinking, paradigm shift. In addition to that the number of indicators proposed were also assesses if applicable. Lastly, the maturity related studies (hence the maturity and circular maturity frameworks) were classified according to the in section Maturity Assessment proposed maturity aspects: maturity type, maturity scope (product, process, company, network), typology (structured models, maturity grids, questionnaires) and components (number of maturity levels, descriptors, level descriptions) (Correia et al., 2017). Detailed information on these classifications is represented in Tables 2, 3 in subsection Thematic Results.

\section{Phase 3-Reporting and Using of Results}

Phase 3 has the goal to report on findings and finally to use this extracted information for further conceptualizations. Section Development of a Maturity Framework in the Circular Supply Chain Context provides the development of a maturity framework in the circular supply chain context by first conceptualizing the circular supply chain concept and second proposing the final maturity framework, its dimensions and maturity levels.

\section{RESEARCH RESULTS}

\section{Descriptive Results}

The SLR's initial research findings are descriptive statistics on the studies found through the search and screening processes. In order to briefly present the article sample selected for further review, the main statistics are reported within this section. It should be noted that the following two statistics refer to the larger set of 222 studies selected for text screening in the second to last step of the review process. First, the number of publications per year is presented to examine the interest in the scientific literature on topics of circular economy, supply chain and maturity assessment as well as their interrelationships. Second, the top 10 journals in which the selected studies were published were evaluated to assess where relevant publications are concentrated.

Figure 5 depicts the studies' distribution over time. The time span ranges from 2006 for the earliest publication to 2021 for the most recent ones. Each in section Phase 1-Locating and Selecting Studies mentioned search string is visualized separately, using different colors to analyze each individual development over time. Given that the first search string yielded only 13 studies (9 after deleting duplicates) and only 3 were selected for further analysis, not much more information than publication dates [2017 and 2019 (2)] can be gleaned from this. Although the second search query delivered 229 studies (84 after deleting duplicates), only 10 were selected for further analysis. These studies were published within the last 4 years: 2018 (2), 2019 (4), and 2021 (4), indicating that maturity assessment in the circular economy context has only recently begun and is thus still in its infancy. Although only these few studies were found through the first two search queries, they nevertheless serve as a basic framework for the developments on maturity assessment within the circular supply chain that will be carried out in the course of this paper. The last two search queries yielded substantially more studies: 1,978 (1,409 after deleting duplicates) 
TABLE 1 | Final set of 35 studies.

\begin{tabular}{|c|c|c|c|c|c|c|}
\hline & & Authors, Year & Title & $\begin{array}{l}\text { Research } \\
\text { type }\end{array}$ & Research purpose & Main findings \\
\hline \multirow[t]{8}{*}{ Circular economy } & 1 & Azevedo et al., 2017 & $\begin{array}{l}\text { Proposal of a sustainable circular } \\
\text { index for manufacturing } \\
\text { companies }\end{array}$ & $\begin{array}{l}\text { Research } \\
\text { Paper }\end{array}$ & $\begin{array}{l}\text { Assessment of } \\
\text { sustainability and } \\
\text { circularity of } \\
\text { manufacturing } \\
\text { companies }\end{array}$ & $\begin{array}{l}\text { Suggestion of a sustainable } \\
\text { circular index formed by a set of } \\
\text { indicators with social, economic, } \\
\text { and environmental sustainability } \\
\text { as well as circularity }\end{array}$ \\
\hline & 3 & Ferreira et al., 2019 & $\begin{array}{l}\text { A proposed index of the } \\
\text { implementation and maturity of } \\
\text { circular economy practices - the } \\
\text { case of the pulp and paper } \\
\text { industries of Portugal and Spain }\end{array}$ & $\begin{array}{l}\text { Research } \\
\text { Paper }\end{array}$ & $\begin{array}{l}\text { Examination of CE } \\
\text { implementation in the } \\
\text { pulp and paper } \\
\text { industries in Portugal } \\
\text { and Spain }\end{array}$ & $\begin{array}{l}\text { Proposition of a comparative } \\
\text { index to support a cross-country } \\
\text { analysis of CE implementation }\end{array}$ \\
\hline & 4 & Genovese et al., 2017 & $\begin{array}{l}\text { Sustainable supply chain } \\
\text { management and the transition } \\
\text { towards a circular economy: } \\
\text { Evidence and some applications }\end{array}$ & $\begin{array}{l}\text { Research } \\
\text { Paper }\end{array}$ & $\begin{array}{l}\text { Analysis of sustainable } \\
\text { supply chain } \\
\text { management in the } \\
\text { light of the CE concept } \\
\text { and its environmental } \\
\text { implications }\end{array}$ & $\begin{array}{l}\text { Comparison of performances of } \\
\text { traditional and circular systems } \\
\text { through indicators: direct, } \\
\text { indirect, and total lifecycle } \\
\text { emissions, waste recovered, } \\
\text { virgin resources use and carbon } \\
\text { maps }\end{array}$ \\
\hline & 5 & $\begin{array}{l}\text { González-Sánchez et al., } \\
2020\end{array}$ & $\begin{array}{l}\text { Main dimensions in the building } \\
\text { of the circular supply chain: a } \\
\text { literature review }\end{array}$ & $\begin{array}{l}\text { Literature } \\
\text { Review }\end{array}$ & $\begin{array}{l}\text { Conceptualization of a } \\
\text { circular supply chain } \\
\text { framework }\end{array}$ & $\begin{array}{l}\text { Proposition of four circular } \\
\text { supply chain dimensions: } \\
\text { relational, logistics and } \\
\text { organizational, technological, } \\
\text { and environmental dimension }\end{array}$ \\
\hline & 6 & $\begin{array}{l}\text { Govindan and Hasanagic, } \\
2018\end{array}$ & $\begin{array}{l}\text { A systematic review on drivers, } \\
\text { barriers, and practices towards } \\
\text { circular economy: a supply chain } \\
\text { perspective }\end{array}$ & $\begin{array}{l}\text { Literature } \\
\text { Review }\end{array}$ & $\begin{array}{l}\text { Systematic analysis of } \\
\text { main drivers, practices, } \\
\text { and barriers to the } \\
\text { implementation of } C E \\
\text { in supply chain } \\
\text { management }\end{array}$ & $\begin{array}{l}\text { Development of a } \\
\text { multi-perspective framework: } \\
\text { external factors (governmental } \\
\text { and societal perspective), } \\
\text { internal factors (consumers' and } \\
\text { suppliers' perspective); } \\
\text { Identification of } 13 \text { drivers, } 34 \\
\text { practices, and } 39 \text { barriers }\end{array}$ \\
\hline & 8 & Jain et al., 2018 & $\begin{array}{l}\text { Strategic framework towards } \\
\text { measuring circular supply chain } \\
\text { management }\end{array}$ & $\begin{array}{l}\text { Conceptual } \\
\text { Paper }\end{array}$ & $\begin{array}{l}\text { Development of a } \\
\text { strategic framework for } \\
\text { measuring circular } \\
\text { supply chain } \\
\text { management }\end{array}$ & $\begin{array}{l}\text { Proposition of a circular supply } \\
\text { chain indicator framework (plan, } \\
\text { source, make deliver, return) and } \\
\text { a three-dimensional strategy for } \\
\text { circular supply chains (strategic, } \\
\text { tactical, operational) }\end{array}$ \\
\hline & 9 & Jia et al., 2020 & $\begin{array}{l}\text { The circular economy in the } \\
\text { textile and apparel industry: a } \\
\text { systematic literature review }\end{array}$ & $\begin{array}{l}\text { Literature } \\
\text { Review }\end{array}$ & $\begin{array}{l}\text { Discovering practices } \\
\text { and performance } \\
\text { aspects of sustainable } \\
\text { supply chain } \\
\text { management toward } \\
\text { CE }\end{array}$ & $\begin{array}{l}\text { Development of an integrated } \\
\text { conceptual framework: CE } \\
\text { practices, drivers, } \\
\text { ex-ante/ex-post barriers, } \\
\text { performance measurement } \\
\text { indicators }\end{array}$ \\
\hline & 10 & Kalmykova et al., 2018 & $\begin{array}{l}\text { Circular economy - from review } \\
\text { of theories and practices to } \\
\text { development of implementation } \\
\text { tools }\end{array}$ & $\begin{array}{l}\text { Literature } \\
\text { Review/ } \\
\text { Research } \\
\text { Paper }\end{array}$ & $\begin{array}{l}\text { Analysis on CE } \\
\text { theoretical approaches, } \\
\text { strategies and } \\
\text { implementation cases } \\
\text { and development of CE } \\
\text { implementation tools }\end{array}$ & $\begin{array}{l}\text { Proposition of a CE strategies } \\
\text { database that serves as a tool } \\
\text { for implementation of CE }\end{array}$ \\
\hline
\end{tabular}


TABLE 1 | Continued

\begin{tabular}{|c|c|c|c|c|c|c|}
\hline & & Authors, Year & Title & $\begin{array}{l}\text { Research } \\
\text { type }\end{array}$ & Research purpose & Main findings \\
\hline & 11 & Khan and Haleem, 2020 & $\begin{array}{l}\text { Strategies to implement circular } \\
\text { economy practices: a fuzzy } \\
\text { DEMANTEL approach }\end{array}$ & $\begin{array}{l}\text { Research } \\
\text { Paper }\end{array}$ & $\begin{array}{l}\text { Investigation of key } \\
\text { strategies in the } \\
\text { adoption of CE } \\
\text { practices }\end{array}$ & $\begin{array}{l}\text { Identification of } 11 \text { final strategies } \\
\text { for the implementation of CE } \\
\text { practices and their analysis using } \\
\text { a DEMATEL-approach }\end{array}$ \\
\hline & 12 & Kravchenko et al., 2019 & $\begin{array}{l}\text { Towards the ex-ante } \\
\text { sustainability screening of } \\
\text { circular economy initiatives in } \\
\text { manufacturing companies: } \\
\text { consolidation of leading } \\
\text { sustainability-related } \\
\text { performance indicators }\end{array}$ & $\begin{array}{l}\text { Literature } \\
\text { Review }\end{array}$ & $\begin{array}{l}\text { Review of leading } \\
\text { sustainability-related } \\
\text { performance indicators } \\
\text { in order to estimate } \\
\text { sustainability effects of } \\
\text { CE strategies }\end{array}$ & $\begin{array}{l}\text { Consolidation of more than } 270 \\
\text { performance indicators and } \\
\text { classification in a database } \\
\text { according to sustainability } \\
\text { dimensions, business processes } \\
\text { and circular economy strategies }\end{array}$ \\
\hline & 13 & Lüdeke-Freund et al., 2018 & $\begin{array}{l}\text { A review and typology of circular } \\
\text { economy business model } \\
\text { patterns }\end{array}$ & $\begin{array}{l}\text { Research } \\
\text { Paper }\end{array}$ & $\begin{array}{l}\text { Analysis of CE } \\
\text { business models, their } \\
\text { patterns and design } \\
\text { options for supporting } \\
\text { circular flows and a } \\
\text { contribution to CE }\end{array}$ & $\begin{array}{l}\text { Proposition of a morphological } \\
\text { box of CE business model } \\
\text { design options (value } \\
\text { proposition, value delivery, value } \\
\text { creation, value capture) }\end{array}$ \\
\hline & 14 & Masi et al., 2018 & $\begin{array}{l}\text { Towards a more circular } \\
\text { economy: exploring the } \\
\text { awareness, practices, and } \\
\text { barriers from a focal firm } \\
\text { perspective }\end{array}$ & $\begin{array}{l}\text { Research } \\
\text { Paper }\end{array}$ & $\begin{array}{l}\text { Investigation of the } \\
\text { implementation of } \\
\text { practices aligned with } \\
\text { CE principles at a focal } \\
\text { firm level }\end{array}$ & $\begin{array}{l}\text { Provision of a comprehensive } \\
\text { taxonomy of practices and } \\
\text { barriers related to the } \\
\text { deployment of the CE at a firm } \\
\text { level }\end{array}$ \\
\hline & 15 & Vegter et al., 2020 & $\begin{array}{l}\text { Supply chains in circular } \\
\text { business models: processes and } \\
\text { performance objectives }\end{array}$ & $\begin{array}{l}\text { Literature } \\
\text { Review/ } \\
\text { Research } \\
\text { Paper }\end{array}$ & $\begin{array}{l}\text { Definition of the } \\
\text { concepts of processes } \\
\text { and performance } \\
\text { objectives of a supply } \\
\text { chain in a circular } \\
\text { business model }\end{array}$ & $\begin{array}{l}\text { Conceptualization of eight } \\
\text { processes (plan, source, make, } \\
\text { deliver, use, return, recover, } \\
\text { enable) and two classifications of } \\
\text { performance objectives for } \\
\text { supply chains in circular } \\
\text { business models }\end{array}$ \\
\hline & 16 & Yadav et al., 2020 & $\begin{array}{l}\text { Exploring indicators of circular } \\
\text { economy adoption framework } \\
\text { through a hybrid decision } \\
\text { support approach }\end{array}$ & $\begin{array}{l}\text { Research } \\
\text { Paper }\end{array}$ & $\begin{array}{l}\text { Identification of CE } \\
\text { indicators in the } \\
\text { context of an emerging } \\
\text { economy, analysis of } \\
\text { their influence and } \\
\text { causal relationships }\end{array}$ & $\begin{array}{l}\text { Identification of } 31 \text { key CE } \\
\text { indicators in } 5 \text { categories } \\
\text { (managerial, organizational, } \\
\text { supply chain, informational and } \\
\text { technological, strategy and } \\
\text { policy) that influence the CE } \\
\text { adoption process }\end{array}$ \\
\hline \multirow[t]{3}{*}{ Maturiy } & 17 & Bibby and Dehe, 2018 & $\begin{array}{l}\text { Defining and assessing industry } \\
4.0 \text { maturity levels - case of the } \\
\text { defense sector }\end{array}$ & $\begin{array}{l}\text { Research } \\
\text { Paper }\end{array}$ & $\begin{array}{l}\text { Development of an } \\
\text { assessment framework } \\
\text { to measure Industry } 4.0 \\
\text { maturity of a focal firm }\end{array}$ & $\begin{array}{l}\text { Proposition of an assessment } \\
\text { framework with three major } \\
\text { dimensions (factory of the future, } \\
\text { people and culture, strategy) on } \\
\text { a 4-level maturity scale (minimal, } \\
\text { development, defined, } \\
\text { excellence) }\end{array}$ \\
\hline & 18 & $\begin{array}{l}\text { Cheshmberah and } \\
\text { Beheshtikia, } 2020\end{array}$ & $\begin{array}{l}\text { Supply chain management } \\
\text { maturity: an all-encompassing } \\
\text { literature review on models, } \\
\text { dimensions and approaches }\end{array}$ & $\begin{array}{l}\text { Literature } \\
\text { Review }\end{array}$ & $\begin{array}{l}\text { Review of maturity } \\
\text { models in the domain } \\
\text { of SCM, especially } \\
\text { review of maturity } \\
\text { models, dimensions, } \\
\text { and approaches for } \\
\text { maturity measurement }\end{array}$ & $\begin{array}{l}\text { Categorization of } 26 \text { different } \\
\text { studies on SCM maturity; } \\
\text { Identification of gaps, especially } \\
\text { missing comprehensive models } \\
\text { for SCM maturity. }\end{array}$ \\
\hline & 19 & Correia et al., 2017 & $\begin{array}{l}\text { Maturity models in supply chain } \\
\text { sustainability: a systematic } \\
\text { literature review }\end{array}$ & $\begin{array}{l}\text { Literature } \\
\text { Review }\end{array}$ & $\begin{array}{l}\text { Providing insights into } \\
\text { methodological issues } \\
\text { related to maturity } \\
\text { models in the supply } \\
\text { chain context }\end{array}$ & $\begin{array}{l}\text { A comprehensive review, } \\
\text { analysis, and synthesis of the } \\
\text { maturity model literature to } \\
\text { contribute to the evolution and } \\
\text { significance of supply chain } \\
\text { maturity }\end{array}$ \\
\hline
\end{tabular}


TABLE 1 | Continued

\begin{tabular}{|c|c|c|c|c|c|}
\hline & Authors, Years & Title & $\begin{array}{l}\text { Research } \\
\text { type }\end{array}$ & Research purpose & Main findings \\
\hline 20 & Almeida Santos et al., 2020 & $\begin{array}{l}\text { Proposal for a maturity model in } \\
\text { sustainability in the supply chain }\end{array}$ & $\begin{array}{l}\text { Literature } \\
\text { Review }\end{array}$ & $\begin{array}{l}\text { Identification of gaps } \\
\text { present in maturity } \\
\text { models in the } \\
\text { sustainable supply } \\
\text { chain management } \\
\text { field }\end{array}$ & $\begin{array}{l}\text { Proposition of a model that aims } \\
\text { to mitigate the identified gaps } \\
\text { (either focus on only one aspect } \\
\text { or excessive broadness) that } \\
\text { offers an integrated } \\
\text { measurement of maturity in } \\
\text { sustainable supply chains }\end{array}$ \\
\hline 21 & Estampe et al., 2013 & $\begin{array}{l}\text { A framework for analysing supply } \\
\text { chain performance evaluation } \\
\text { models }\end{array}$ & $\begin{array}{l}\text { Literature } \\
\text { Review }\end{array}$ & $\begin{array}{l}\text { Analysis of various } \\
\text { models used to assess } \\
\text { supply chain maturity }\end{array}$ & $\begin{array}{l}\text { Comparison of different maturity } \\
\text { models and distinction between } \\
\text { two main categories of models: } \\
\text { (1) models targeting companies } \\
\text { intra and interorganizational } \\
\text { maturity levels, (2) models } \\
\text { targeting maturity of extended, } \\
\text { multi-chain or societal } \\
\text { organizations }\end{array}$ \\
\hline 22 & Ferreira et al., 2019 & $\begin{array}{l}\text { Maturity levels of material cycles } \\
\text { and waste management in a } \\
\text { context of green supply chain } \\
\text { management: an innovative } \\
\text { framework and its application to } \\
\text { Brazilian cases }\end{array}$ & $\begin{array}{l}\text { Research } \\
\text { Paper + Case } \\
\text { Study }\end{array}$ & $\begin{array}{l}\text { Analysis of the } \\
\text { relationship between } \\
\text { the maturity of } \\
\text { environmental } \\
\text { management and the } \\
\text { adoption of green } \\
\text { supply chain } \\
\text { management practices }\end{array}$ & $\begin{array}{l}\text { Proposition of an integrative } \\
\text { framework with } 3 \text { green supply } \\
\text { chain management maturity } \\
\text { levels: reactive (low adoption of } \\
\text { GSCM practices), preventive } \\
\text { (average adoption of GSCM), } \\
\text { proactive (pursuit of competitive } \\
\text { advantages) }\end{array}$ \\
\hline 23 & Frederico et al., 2019 & $\begin{array}{l}\text { Supply Chain 4.0: concepts, } \\
\text { maturity and research agenda }\end{array}$ & $\begin{array}{l}\text { Literature } \\
\text { Review/ } \\
\text { Research } \\
\text { Paper }\end{array}$ & $\begin{array}{l}\text { Analysis of constructs } \\
\text { that shape the Supply } \\
\text { Chain } 4.0 \text { concept, its } \\
\text { evolution and } \\
\text { evaluation }\end{array}$ & $\begin{array}{l}\text { Proposition of a Supply Chain } \\
4.0 \text { maturity framework with } 4 \\
\text { constructs (managerial and } \\
\text { capability supporters, technology } \\
\text { levers, process performances, } \\
\text { strategic outcomes) in } 4 \text { maturity } \\
\text { levels }\end{array}$ \\
\hline 24 & $\begin{array}{l}\text { Garcia Reyes and Giachetti, } \\
2010\end{array}$ & $\begin{array}{l}\text { Using experts to develop a } \\
\text { supply chain maturity model in } \\
\text { Mexico }\end{array}$ & $\begin{array}{l}\text { Research } \\
\text { Paper }\end{array}$ & $\begin{array}{l}\text { Analysis of supply } \\
\text { chain maturity in } \\
\text { Mexican companies } \\
\text { using experts and the } \\
\text { Delphi method }\end{array}$ & $\begin{array}{l}\text { Development of a supply chain } \\
\text { capability maturity model that } \\
\text { intends to help firms evaluate } \\
\text { their supply chain operations and } \\
\text { to develop a roadmap to improve } \\
\text { capabilities }\end{array}$ \\
\hline 25 & $\begin{array}{l}\text { Golinska-Dawson et al., } \\
2021\end{array}$ & $\begin{array}{l}\text { Responsible resource } \\
\text { management in remanufacturing } \\
\text { - framework for qualitative } \\
\text { assessment of SMEs }\end{array}$ & $\begin{array}{l}\text { Research } \\
\text { Paper }\end{array}$ & $\begin{array}{l}\text { Providing insights on } \\
\text { responsible resource } \\
\text { management in a } \\
\text { remanufacturing } \\
\text { process }\end{array}$ & $\begin{array}{l}\text { Proposition of a two-layered } \\
\text { framework, using the maturity } \\
\text { model theory, to scan } \\
\text { remanufacturing processes }\end{array}$ \\
\hline 26 & McCormack et al., 2008 & $\begin{array}{l}\text { Supply chain maturity and } \\
\text { performance in Brazil }\end{array}$ & $\begin{array}{l}\text { Research } \\
\text { Paper }\end{array}$ & $\begin{array}{l}\text { Investigating the } \\
\text { relationship between } \\
\text { supply chain maturity } \\
\text { and performance }\end{array}$ & $\begin{array}{l}\text { Based on a quantitative survey } \\
\text { with } 478 \text { Brazilian companies it } \\
\text { was found that there is a strong } \\
\text { and positive statistical } \\
\text { relationship between supply } \\
\text { chain maturity and performance }\end{array}$ \\
\hline 27 & $\begin{array}{l}\text { Vaidyanathan and Howell, } \\
2007\end{array}$ & $\begin{array}{l}\text { Construction supply chain } \\
\text { maturity model - conceptual } \\
\text { framework }\end{array}$ & $\begin{array}{l}\text { Conference } \\
\text { Paper }\end{array}$ & $\begin{array}{l}\text { Provision of a roadmap } \\
\text { for realizing the } \\
\text { operational excellence } \\
\text { in construction projects }\end{array}$ & $\begin{array}{l}\text { Presentation of a conceptual } \\
\text { framework of construction } \\
\text { supply chain maturity aiming to } \\
\text { remove inefficiencies }\end{array}$ \\
\hline 28 & Zhao et al., 2006 & $\begin{array}{l}\text { A new supply chain maturity } \\
\text { model with } 3 \text {-dimension } \\
\text { perspective }\end{array}$ & $\begin{array}{l}\text { Conference } \\
\text { Paper }\end{array}$ & $\begin{array}{l}\text { Review and evaluation } \\
\text { of typical supply chain } \\
\text { maturity models }\end{array}$ & $\begin{array}{l}\text { Proposition of a new model that } \\
\text { defines supply chain maturity } \\
\text { and offers three sub-models for } \\
\text { evaluating and improving supply } \\
\text { chain according to a } \\
\text { 3-dimensional perspective } \\
\text { (environmental, resource, } \\
\text { management dimension) }\end{array}$ \\
\hline
\end{tabular}


TABLE 1 | Continued

\begin{tabular}{|c|c|c|c|c|c|c|}
\hline & & Authors, Year & Title & $\begin{array}{l}\text { Research } \\
\text { type }\end{array}$ & Research purpose & Main findings \\
\hline \multirow[t]{7}{*}{ Circular maturity } & 29 & Cristoni and Tonelli, 2018 & $\begin{array}{l}\text { Perceptions of firms participating } \\
\text { in a circular economy }\end{array}$ & $\begin{array}{l}\text { Research } \\
\text { Paper }\end{array}$ & $\begin{array}{l}\text { Identification of } \\
\text { business areas for CE } \\
\text { implementation; } \\
\text { Establishing firms' } \\
\text { perceptions of CE } \\
\text { relevance and CE } \\
\text { maturity }\end{array}$ & $\begin{array}{l}\text { Proposition of } 17 \text { circular actions } \\
\text { within } 5 \text { key areas: design, } \\
\text { sourcing, production, } \\
\text { distribution, use, end use }\end{array}$ \\
\hline & 30 & Gorecki, 2019 & $\begin{array}{l}\text { Circular economy maturity in } \\
\text { construction companies }\end{array}$ & $\begin{array}{l}\text { Conference } \\
\text { Paper }\end{array}$ & $\begin{array}{l}\text { Analysis of the role of } \\
\text { construction } \\
\text { enterprises in } \\
\text { implementing CE at } \\
\text { process and product } \\
\text { level }\end{array}$ & $\begin{array}{l}\text { Definition of CE maturity; } \\
\text { Proposition of CE indicators: } \\
\text { workgroup level, processes level } \\
\text { and organization level }\end{array}$ \\
\hline & 31 & Sacco et al., 2021 & $\begin{array}{l}\text { Circular economy at the firm } \\
\text { level: a new tool for assessing } \\
\text { maturity and circularity }\end{array}$ & $\begin{array}{l}\text { Research } \\
\text { Paper }\end{array}$ & $\begin{array}{l}\text { Development of a new } \\
\text { circularity and maturity } \\
\text { firm-level assessment } \\
\text { tool }\end{array}$ & $\begin{array}{l}\text { Proposition of (separate) CE and } \\
\text { maturity performance } \\
\text { assessment as a tool for } \\
\text { companies to boost and/or } \\
\text { introduce CE-oriented business } \\
\text { models, products, and } \\
\text { processes }\end{array}$ \\
\hline & 32 & Sehnem et al., 2019a & $\begin{array}{l}\text { Circular business models: levels } \\
\text { of maturity }\end{array}$ & $\begin{array}{l}\text { Research } \\
\text { Paper }\end{array}$ & $\begin{array}{l}\text { Analysis of circular } \\
\text { business models of } \\
\text { Brazilian companies } \\
\text { and their level of } \\
\text { maturity }\end{array}$ & $\begin{array}{l}\text { Development of determinants of } \\
\text { the circularity of resources in the } \\
\text { production chain; differentiation } \\
\text { between technical and biological } \\
\text { cycle }\end{array}$ \\
\hline & 33 & Sehnem et al., 2019b & $\begin{array}{l}\text { Improving sustainable supply } \\
\text { chains performance through } \\
\text { operational excellence: circular } \\
\text { economy approach }\end{array}$ & $\begin{array}{l}\text { Research } \\
\text { Paper }\end{array}$ & $\begin{array}{l}\text { Analysis of critical } \\
\text { success factors for the } \\
\text { CE adoption and their } \\
\text { management by } \\
\text { companies }\end{array}$ & $\begin{array}{l}\text { Alignment between CE } \\
\text { proactivity and management of } \\
\text { critical success factors: more CE } \\
\text { proactivity leads to better } \\
\text { management of critical success } \\
\text { factors and more sustainability }\end{array}$ \\
\hline & 34 & Sehnem et al., 2019c & $\begin{array}{l}\text { Circular economy in the wine } \\
\text { chain production: maturity, } \\
\text { challenges, and lessons from an } \\
\text { emerging economy perspective }\end{array}$ & $\begin{array}{l}\text { Research } \\
\text { Paper }\end{array}$ & $\begin{array}{l}\text { Analysis of relationship } \\
\text { between maturity } \\
\text { stages of CE practices } \\
\text { adoption and circular } \\
\text { business models }\end{array}$ & $\begin{array}{l}\text { Proposition: levels of maturity } \\
\text { and time of adoption of CE } \\
\text { practices as well as business } \\
\text { model of CE and levels of } \\
\text { maturity are positively }\end{array}$ \\
\hline & 35 & Ünal and Shao, 2019 & $\begin{array}{l}\text { A Taxonomy of Circular Economy } \\
\text { Implementation Strategies for } \\
\text { Manufacturing Firms: analysis of } \\
391 \text { Cradle-to-Cradle Products }\end{array}$ & $\begin{array}{l}\text { Research } \\
\text { Paper }\end{array}$ & $\begin{array}{l}\text { Understanding CE } \\
\text { implementation from a } \\
\text { strategic management } \\
\text { perspective }\end{array}$ & $\begin{array}{l}\text { Proposition of a taxonomy with } \\
\text { three degrees of circularity } \\
\text { adopting different strategies; } \\
\text { maturity degree of a competitive } \\
\text { capability determines the } \\
\text { strategy }\end{array}$ \\
\hline
\end{tabular}

and 2,837 (2,143 after deleting duplicates), of which a total of 209 studies was selected for in-depth analysis on circular supply chains and maturity in the supply chain context. Their development over time shows very different characteristics: while the last search string on maturity and supply chains ranges from 2006 to 2021 and shows only a slight and steady overall increase, relevant results for circular supply chains can only be obtained from 2016 onwards, with a sharp increase in number of publications, especially from 2018 onwards. In particular the latter development-the combination of circular thinking and supply chain management-and thus the emergence of a new and rapidly evolving field of research is an important driver for our study and the rationale for building a maturity model for the circular supply chain.
Figure 6 illustrates the studies' distribution by source title and shows the top 10 journals found for the 222 study set. In total, there are 105 different source titles (journals, edited volumes, conference proceedings, etc.) in which the selected studies were published. Eighty-one sources only published one study each, 13 sources published two studies each and one source published three articles. Within the top 10, all source titles published four or more studies. The Journal of Cleaner Production is the most important source title for the search queries applied, publishing 33 studies $(\sim 15 \%)$. This result is not surprising as this journal is known for its focus on interdisciplinary research on environmental science and sustainability. The journals Sustainability and Resources, Conservation, and Recycling rank second (22 studies) and third (12 studies). 
TABLE 2 | Subset circular economy studies.

\begin{tabular}{|c|c|c|c|c|c|c|c|c|c|}
\hline & $\#$ & References & \multicolumn{6}{|c|}{ Circular economy and circular supply chain archetypal elements } & $\begin{array}{l}\text { Number of } \\
\text { indicators }\end{array}$ \\
\hline \multirow[t]{10}{*}{ Circular economy } & 1 & Azevedo et al., 2017 & $x$ & & $(X)$ & $x$ & $x$ & & $1(4 \mid 17)$ \\
\hline & 2 & Bracquené et al., 2020 & $x$ & $(X)$ & & $(X)$ & $x$ & & $1(13)$ \\
\hline & 5 & $\begin{array}{l}\text { González-Sánchez } \\
\text { et al., } 2020\end{array}$ & $x$ & $x$ & $(X)$ & & $x$ & $(X)$ & n.a. \\
\hline & 6 & $\begin{array}{l}\text { Govindan and } \\
\text { Hasanagic, } 2018\end{array}$ & $x$ & $x$ & $(X)$ & $x$ & $x$ & & n.a. \\
\hline & 7 & Howard et al., 2018 & $x$ & $x$ & & $(X)$ & $x$ & & 7 \\
\hline & 12 & Kravchenko et al., 2019 & $x$ & & $x$ & & & $x$ & n.a. \\
\hline & 13 & $\begin{array}{l}\text { Lüdeke-Freund et al., } \\
2018\end{array}$ & $x$ & $x$ & $(X)$ & $x$ & & $(X)$ & $4 \mid 8$ \\
\hline & 14 & Masi et al., 2018 & $x$ & $x$ & $(X)$ & $x$ & $x$ & & $2 \mid 12$ \\
\hline & 15 & Vegter et al., 2020 & $x$ & $(X)$ & $x$ & $x$ & $x$ & $(X)$ & n.a. \\
\hline & 16 & Yadav et al., 2020 & $x$ & & & & $x$ & & $5 \mid 31$ \\
\hline \multirow[t]{3}{*}{ Circular maturity } & 29 & $\begin{array}{l}\text { Cristoni and Tonelli, } \\
2018\end{array}$ & $x$ & $x$ & & $x$ & $x$ & & n.a. \\
\hline & 30 & Gorecki, 2019 & $(X)$ & & $x$ & & $(X)$ & & $15 \mid 6$ \\
\hline & 31 & Sacco et al., 2021 & $x$ & & $(X)$ & $x$ & & & $7 \mid 12$ \\
\hline
\end{tabular}

$X$ - element included in reference. $(X)$ - element partially included in reference.

After presenting the main characteristics of all 222 studies selected for further in-depth analysis, the focus is now on the final set of 35 publications. Before providing thematic details in subsection Thematic Results, Table 1 shows further descriptive results, i.e., the studies' authors, titles, year of publication, the research type and purpose as well as the main findings of the studies. The first 16 studies of the final set focus on the circular economy concept, providing insights on circularity assessment, circular performances within supply chains, developing circular indicators and investigating circular practices and strategies. Twelve studies address the context of (supply chain) maturity, proposing maturity models, frameworks, and levels for the assessment of supply chain maturity. Lastly, seven studies were selected for the final set that contribute insights on maturity within the circular economy context, such as the maturity assessment of circular business models or the proposition of circularity determinants.

\section{Thematic Results}

For the thematic analysis of each article listed in Table 1, the set of 35 studies was divided into two focus groups: the first includes all articles dealing with circular economy, thus the 16 studies solely focusing on circular economy and the seven studies that address circular maturity; the second group then accordingly contains the 11 articles dealing with maturity assessment of supply chains and in addition the seven studies focusing on circular maturity. At this point, it should be noted that additional studies on maturity assessment were included in the thematic analysis, further details on these studies follow later on.

Each of the 23 studies addressing the concept of the circular economy was thoroughly analyzed. In particular, this subset was examined in terms of the proposed circular economy and circular supply chain archetypal elements. In addition to that, potential indicators of the circular economy were screened for. Table 2 presents the results of this analysis, depicting which 
TABLE 3 | Subset maturity studies.

\begin{tabular}{|c|c|c|c|c|c|c|c|c|c|c|c|c|c|}
\hline & \multirow[b]{2}{*}{$\#$} & \multirow[b]{2}{*}{ References } & \multirow[b]{2}{*}{ Maturity type } & \multicolumn{4}{|c|}{ Maturity scope } & \multicolumn{3}{|c|}{ Typology } & \multicolumn{3}{|c|}{ Components } \\
\hline & & & & Product & Process & Company & Network & $\begin{array}{l}\text { Structured } \\
\text { models }\end{array}$ & $\begin{array}{l}\text { d Maturity } \\
\text { grids }\end{array}$ & Questionnaires & $\begin{array}{l}\text { \# of } \\
\text { Maturity } \\
\text { levels }\end{array}$ & Descriptors & $\begin{array}{l}\text { Level } \\
\text { descriptions }\end{array}$ \\
\hline \multirow[t]{11}{*}{ Maturity } & 17 & $\begin{array}{l}\text { Bibby and Dehe, } \\
2018\end{array}$ & Industry 4.0 & & $x$ & $x$ & & & $x$ & & 4 & $\begin{array}{l}1=\text { Minimal, } 3= \\
\text { Development, } 3=\text { Defined } \\
4=\text { Excellence }\end{array}$ & Yes (numerical) \\
\hline & 18 & $\begin{array}{l}\text { Cheshmberah and } \\
\text { Beheshtikia, } 2020\end{array}$ & & & eview of 25 & Supply Chain & Manageme & ent (Maturity) & Models $\rightarrow$ & 11 of them were id & lentified as & relevant for this study & \\
\hline & a & $\begin{array}{l}\text { van Landeghem } \\
\text { and Persoons, } \\
2001\end{array}$ & $\begin{array}{l}\text { Supply Chain and } \\
\text { Logistics } \\
\text { Management }\end{array}$ & & & & $x$ & & $x$ & & 5 & None & No \\
\hline & $b$ & $\begin{array}{l}\text { Lockamy and } \\
\text { McCormack, } 2004\end{array}$ & $\begin{array}{l}\text { Supply Chain } \\
\text { Management }\end{array}$ & & $x$ & & $x$ & & $x$ & & 5 & $\begin{array}{l}\text { 1: Ad-hoc; 2: Defined; 3: } \\
\text { Linked; 4: Integrated; 5: } \\
\text { Extended }\end{array}$ & \\
\hline & $c$ & $\begin{array}{l}\text { Seong Leem and } \\
\text { Yoon, } 2004\end{array}$ & $\begin{array}{l}\text { (Software) } \\
\text { Customer } \\
\text { Satisfaction }\end{array}$ & $x$ & $x$ & & & & $x$ & & 4 & $\begin{array}{l}\text { Initial Level, Ready Made } \\
\text { Level, Tailored Level, } \\
\text { Customer-Oriented Level }\end{array}$ & Yes (numerical) \\
\hline & $d$ & IBM, 2005 & $\begin{array}{l}\text { Supply Chain } \\
\text { Maturity } \\
\text { (Collaboration) }\end{array}$ & & & & $x$ & & $x$ & & 5 & $\begin{array}{l}\text { Static, Functional } \\
\text { Excellence, Horizontal } \\
\text { Integration, External } \\
\text { participation } \\
\text { Demand-Based Supply } \\
\text { Chain }\end{array}$ & Yes (descriptive) \\
\hline & $e$ & $\begin{array}{l}\text { Aberdeen Group, } \\
2006\end{array}$ & $\begin{array}{l}\text { Supply Chain } \\
\text { Visibility }\end{array}$ & & & & $x$ & & & $(X)$ & 3 & $\begin{array}{l}\text { Shipment Tracking } \\
\text { Capability, Supply Chain } \\
\text { Disruption Management, } \\
\text { Supply Chain Improvement }\end{array}$ & Yes (descriptive) \\
\hline & $f$ & Jaklič et al., 2006 & $\begin{array}{l}\text { Lean Supply Chain } \\
\text { Maturity } \\
\text { (Application of } \\
\text { SCOR) }\end{array}$ & & $x$ & & $x$ & & $x$ & & 5 & $\begin{array}{l}\text { 1: Ad-hoc; 2: Defined; 3: } \\
\text { Linked; 4: Integrated; 5: } \\
\text { Extended }\end{array}$ & Yes (descriptive) \\
\hline & $g$ & SCOR, 2012 & $\begin{array}{l}\text { Supply Chain } \\
\text { Operations }\end{array}$ & & $x$ & & $x$ & & $x$ & & & None & No \\
\hline & $h$ & Garcia, 2008 & $\begin{array}{l}\text { Supply Chain } \\
\text { Capability Maturity }\end{array}$ & & & $x$ & $x$ & & $x$ & & 5 & $\begin{array}{l}\text { Undefined, Defined, } \\
\text { Manageable, Collaborative, } \\
\text { Leading }\end{array}$ & Yes (descriptive) \\
\hline & i & Lahti et al., 2009 & $\begin{array}{l}\text { Performance of a } \\
\text { Supply Network }\end{array}$ & & & & $x$ & & & $x$ & 4 & $\begin{array}{l}\text { Functional Focus, Internal } \\
\text { Integration, External } \\
\text { Integration, } \\
\text { Cross-Enterprise } \\
\text { Collaboration }\end{array}$ & Yes (descriptive) \\
\hline
\end{tabular}


TABLE 3 | Continued

\begin{tabular}{|c|c|c|c|c|c|c|c|c|c|c|c|c|}
\hline \multirow[b]{2}{*}{$\#$} & \multirow[b]{2}{*}{ References } & \multirow[b]{2}{*}{ Maturity type } & \multicolumn{4}{|c|}{ Maturity scope } & \multicolumn{3}{|c|}{ Typology } & \multicolumn{3}{|c|}{ Components } \\
\hline & & & Product & Process & Company & Network & $\begin{array}{l}\text { Structured } \\
\text { models }\end{array}$ & $\begin{array}{l}\text { d Maturity } \\
\text { grids }\end{array}$ & Questionnaires & $\begin{array}{l}\text { \# of } \\
\text { Maturity } \\
\text { levels }\end{array}$ & Descriptors & $\begin{array}{l}\text { Level } \\
\text { descriptions }\end{array}$ \\
\hline j & Accenture, 2012 & Supply Chain & & & & $x$ & & $x$ & & 4 & $\begin{array}{l}\text { Focused on Tasks and } \\
\text { Business Units, Focus on } \\
\text { Efficiency (Cost), Demand } \\
\text { Driven, Value Driven }\end{array}$ & Yes (descriptive) \\
\hline k & $\begin{array}{l}\text { Sartori and } \\
\text { Frederico, } 2017\end{array}$ & Supply Chain & & & & $x$ & $(X)$ & & & n.a. & None & No \\
\hline 19 & Correia et al., 2017 & & & Review of $S$ & upply Chain & Sustainability & (Maturity) M & Models $\rightarrow 1$ & 1 of them were ider & ntified as re & levant for this study & \\
\hline a & $\begin{array}{l}\text { Babin and } \\
\text { Nicholson, } 2011\end{array}$ & $\begin{array}{l}\text { Sustainability in IT } \\
\text { Outsourcing }\end{array}$ & & & $x$ & & & $x$ & & 3 & $\begin{array}{l}\text { Early Stage, Aspirant, } \\
\text { Mature Leaders }\end{array}$ & Yes (descriptive) \\
\hline$b$ & $\begin{array}{l}\text { Pigosso et al., } \\
2013\end{array}$ & Eco Design & & $x$ & & & & & & 5 & Level 1-5 & Yes (descriptive) \\
\hline$c$ & Hynds et al., 2014 & $\begin{array}{l}\text { New Product } \\
\text { Development }\end{array}$ & & $x$ & & & & & 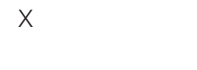 & 4 & $\begin{array}{l}\text { Beginning, Improving, } \\
\text { Succeeding, Leading }\end{array}$ & Yes (descriptive) \\
\hline$d$ & $\begin{array}{l}\text { Robinson et al., } \\
2006\end{array}$ & $\begin{array}{l}\text { Knowledge } \\
\text { Management }\end{array}$ & & $\mathrm{x}$ & & & & $x$ & & 5 & $\begin{array}{l}\text { Start-up, Take-off, } \\
\text { Expansion, Progressive, } \\
\text { Sustainability }\end{array}$ & Yes (descriptive) \\
\hline e & $\begin{array}{l}\text { Standing and } \\
\text { Jackson, } 2007\end{array}$ & $\begin{array}{l}\text { Information } \\
\text { System } \\
\text { Management }\end{array}$ & & $x$ & & & & & & 6 & $\begin{array}{l}\text { Non-existent, initial/ad-hoc, } \\
\text { repeatable but intuitive, } \\
\text { defined process, Managed } \\
\text { and Measurable, Optimized }\end{array}$ & Yes (descriptive) \\
\hline$f$ & $\begin{array}{l}\text { Okongwu et al., } \\
2013\end{array}$ & $\begin{array}{l}\text { Sustainability } \\
\text { Disclosure/Reportins }\end{array}$ & & & & $x$ & & $x$ & & 5 & $\begin{array}{l}\text { Primeval, Initial, } \\
\text { Intermediate, Advanced, } \\
\text { World Class }\end{array}$ & Yes (descriptive) \\
\hline$g$ & Srai et al., 2013 & $\begin{array}{l}\text { Sustainable } \\
\text { Supply Network } \\
\text { Capabilities }\end{array}$ & & & & $x$ & & $x$ & & 5 & None & Yes (descriptive) \\
\hline$h$ & Reefke et al., 2014 & $\begin{array}{l}\text { Sustainable } \\
\text { Supply Chain } \\
\text { Management }\end{array}$ & & & & $x$ & & $x$ & & 6 & $\begin{array}{l}\text { Unaware and } \\
\text { Non-compliant, Ad-hoc and } \\
\text { Compliance Basic, Defined } \\
\text { and Compliance, Linked } \\
\text { and Exceeds Compliance, } \\
\text { Integrated and Proactive, } \\
\text { Extended and Sustainability } \\
\text { Leadership }\end{array}$ & Yes (descriptive) \\
\hline$i$ & Kurnia et al., 2014 & $\begin{array}{l}\text { Capabilities for } \\
\text { Sustainable } \\
\text { Supply Chains }\end{array}$ & & & & $x$ & & $x$ & & 4 & $\begin{array}{l}\text { Unaware, Unprepared, } \\
\text { Committed, Advanced }\end{array}$ & Yes (descriptive) \\
\hline
\end{tabular}


TABLE 3 | Continued

\begin{tabular}{|c|c|c|c|c|c|c|c|c|c|c|c|c|}
\hline \multirow[b]{2}{*}{ \# } & \multirow[b]{2}{*}{ References } & \multirow[b]{2}{*}{ Maturity type } & \multicolumn{4}{|c|}{ Maturity scope } & \multicolumn{3}{|c|}{ Typology } & \multicolumn{3}{|c|}{ Components } \\
\hline & & & Product & Process & Company & Network & $\begin{array}{l}\text { Structurec } \\
\text { models }\end{array}$ & $\begin{array}{l}\text { d Maturity } \\
\text { grids }\end{array}$ & Questionnaires & $\begin{array}{l}\text { \# of } \\
\text { Maturity } \\
\text { levels }\end{array}$ & Descriptors & $\begin{array}{l}\text { Level } \\
\text { descriptions }\end{array}$ \\
\hline j & $\begin{array}{l}\text { Golinska and } \\
\text { Kuebler, } 2014\end{array}$ & $\begin{array}{l}\text { Sustainability in } \\
\text { Remanufacturing }\end{array}$ & & & $x$ & & & & $x$ & 5 & Level 0-4 & Yes (descriptive) \\
\hline k & $\begin{array}{l}\text { Edgeman and } \\
\text { Eskildsen, } 2014\end{array}$ & $\begin{array}{l}\text { Sustainable } \\
\text { Enterprise } \\
\text { Excellence }\end{array}$ & & & $x$ & & & & $x$ & 5 & $\begin{array}{l}\text { Very Low, Low, Medium, } \\
\text { High, Very High }\end{array}$ & Yes (descriptive) \\
\hline 20 & $\begin{array}{l}\text { Almeida Santos } \\
\text { et al., } 2020\end{array}$ & $\begin{array}{l}\text { Supply Chain } \\
\text { Sustainability }\end{array}$ & $x$ & & $x$ & $x$ & $x$ & & & 5 & $\begin{array}{l}\text { Non-existent, Aware, } \\
\text { Intermediate, Advanced, } \\
\text { Sustainable }\end{array}$ & Yes (descriptive) \\
\hline 21 & $\begin{array}{l}\text { Estampe et al., } \\
2013\end{array}$ & Review of 16 & Supply Ch & in Performa & nce Measure & ement Mode & Is $\rightarrow 4$ of the & em were ide & entified as relevant $f$ & for this stud & y (SCOR has already been ana & alyzed before) \\
\hline a & $\begin{array}{l}\text { GSCF, Cooper } \\
\text { et al., } 1997\end{array}$ & $\begin{array}{l}\text { Supply Chain } \\
\text { Management }\end{array}$ & $x$ & $x$ & & $x$ & & $x$ & & n.a. & None & No \\
\hline$b$ & EFQM, 2010 & $\begin{array}{l}\text { Total Quality } \\
\text { Management }\end{array}$ & $x$ & $x$ & $x$ & $x$ & & & $x$ & 3 & $\begin{array}{l}\text { Committed to Excellence, } \\
\text { Recognized for Excellence, } \\
\text { Excellence Award }\end{array}$ & Yes (Numerical) \\
\hline$c$ & $\begin{array}{l}\text { Favre Bertin and } \\
\text { Estampe, } 2004\end{array}$ & $\begin{array}{l}\text { Supply Chain } \\
\text { Management - } \\
\text { Logistic }\end{array}$ & & $x$ & & $x$ & & & $x$ & n.a. & None & No \\
\hline 22 & $\begin{array}{l}\text { Ferreira et al., } \\
2017\end{array}$ & $\begin{array}{l}\text { Material Cycles } \\
\text { and Waste } \\
\text { Management }\end{array}$ & $x$ & $x$ & & & $x$ & & & 3 & $\begin{array}{l}\text { Reactive, Preventive, } \\
\text { Proactive }\end{array}$ & Yes (descriptive) \\
\hline 23 & $\begin{array}{l}\text { Frederico et al., } \\
2019\end{array}$ & $\begin{array}{l}\text { Supply Chain and } \\
\text { Industry } 4.0\end{array}$ & & & & $x$ & & $x$ & & 4 & $\begin{array}{l}\text { Initiate, Intermediate, } \\
\text { Advanced, Cutting-Edge }\end{array}$ & Yes (descriptive) \\
\hline 24 & $\begin{array}{l}\text { Garcia Reyes and } \\
\text { Giachetti, } 2010\end{array}$ & $\begin{array}{l}\text { Supply Chain } \\
\text { Maturity }\end{array}$ & & $x$ & $x$ & $x$ & & & $x$ & 5 & $\begin{array}{l}\text { 1: Undefined, 2: Defined, 3: } \\
\text { Manageable, 4: } \\
\text { Collaborative, 5: Leading }\end{array}$ & Yes (descriptive) \\
\hline 25 & $\begin{array}{l}\text { Golinska-Dawson } \\
\text { et al., } 2021\end{array}$ & $\begin{array}{l}\text { Responsible } \\
\text { Resource } \\
\text { Management in } \\
\text { SME }\end{array}$ & & $x$ & & & $x$ & & & 5 & $\begin{array}{l}\text { Very Low, Low, Medium, } \\
\text { High, Very High }\end{array}$ & Yes (numerical) \\
\hline
\end{tabular}


TABLE 3 | Continued

\begin{tabular}{|c|c|c|c|c|c|c|c|c|c|c|c|c|c|}
\hline & \multirow[b]{2}{*}{$\#$} & \multirow[b]{2}{*}{ References } & \multirow[b]{2}{*}{ Maturity type } & \multicolumn{4}{|c|}{ Maturity scope } & \multicolumn{3}{|c|}{ Typology } & \multicolumn{3}{|c|}{ Components } \\
\hline & & & & Product & Process & Company & Network & $\begin{array}{l}\text { Structurec } \\
\text { models }\end{array}$ & $\begin{array}{l}\text { Maturity } \\
\text { grids }\end{array}$ & Questionnaires & $\begin{array}{l}\text { \# of } \\
\text { Maturity } \\
\text { levels }\end{array}$ & Descriptors & $\begin{array}{l}\text { Level } \\
\text { descriptions }\end{array}$ \\
\hline & 26 & $\begin{array}{l}\text { McCormack et al., } \\
2008\end{array}$ & $\begin{array}{l}\text { Supply Chain } \\
\text { Maturity and } \\
\text { Performance }\end{array}$ & & $x$ & & & $x$ & & $x$ & 5 & $\begin{array}{l}\text { Ad-hoc, Defined, Linked, } \\
\text { Integrated, Extended }\end{array}$ & Yes (descriptive) \\
\hline & 27 & $\begin{array}{l}\text { Vaidyanathan and } \\
\text { Howell, } 2007\end{array}$ & $\begin{array}{l}\text { Construction } \\
\text { Supply Chain } \\
\text { Management }\end{array}$ & & $x$ & $x$ & & & $x$ & & 4 & $\begin{array}{l}\text { Ad-hoc, Defined, Managed, } \\
\text { Controlled }\end{array}$ & Yes (descriptive) \\
\hline & 28 & Zhao et al., 2006 & $\begin{array}{l}\text { Supply Chain } \\
\text { (Management, } \\
\text { Resource, } \\
\text { Environment) }\end{array}$ & & $x$ & $x$ & & & $x$ & & 4 & Stage 1-4 & Yes (descriptive) \\
\hline \multirow[t]{7}{*}{ Circular maturity } & 29 & $\begin{array}{l}\text { Cristoni and } \\
\text { Tonelli, } 2018\end{array}$ & Circular Economy & & & $x$ & & & & $x$ & 5 & $\begin{array}{l}1=\text { Very Low, } 2=\text { Low, } 3= \\
\text { Medium, } 4=\text { High, } 5=\text { Very } \\
\text { High }\end{array}$ & No \\
\hline & 30 & Gorecki, 2019 & Circular Economy & $x$ & $x$ & & & & n.a. & & n.a. & n.a. & No \\
\hline & 31 & Sacco et al., 2021 & Circular Economy & $x$ & $x$ & $x$ & $(X)$ & & & $x$ & 0-100\% & None & No \\
\hline & 32 & $\begin{array}{l}\text { Sehnem et al., } \\
2019 a\end{array}$ & $\begin{array}{l}\text { Circular Business } \\
\text { Model }\end{array}$ & & & $x$ & & & $x$ & & 6 & $\begin{array}{l}0=\text { Non-existent, } 1= \\
\text { Executed, } 2=\text { Managed, } 3 \\
=\text { Established, } 4= \\
\text { Predictable, } 5=\text { Optimized }\end{array}$ & Yes (descriptive) \\
\hline & 33 & $\begin{array}{l}\text { Sehnem et al., } \\
\text { 2019b }\end{array}$ & Circular Economy & & & $x$ & & & & $x$ & 3 & $\begin{array}{l}\text { partially proactive, more } \\
\text { proactive, the most } \\
\text { proactive }\end{array}$ & Yes (descriptive) \\
\hline & 34 & $\begin{array}{l}\text { Sehnem et al., } \\
\text { 2019c }\end{array}$ & $\begin{array}{l}\text { Circular } \\
\text { Economy/Circular } \\
\text { Business Model }\end{array}$ & & & $x$ & & & & $x$ & 6 & $\begin{array}{l}0=\text { Non-existent, } 1= \\
\text { Executed, } 2=\text { Managed, } 3 \\
=\text { Established, } 4= \\
\text { Predictable, } 5=\text { Optimized }\end{array}$ & Yes (descriptive) \\
\hline & 35 & $\begin{array}{l}\text { Ünal and Shao, } \\
2019\end{array}$ & Circular Economy & $x$ & & & & & $x$ & & 3 & $\begin{array}{l}\text { Founding/recyclers, } \\
\text { development/all-decent } \\
\text { circulars, maturity/toxicity } \\
\text { fighters }\end{array}$ & Yes (descriptive) \\
\hline
\end{tabular}

$X$ - element included in reference. $(X)$ - element partially included in reference. 


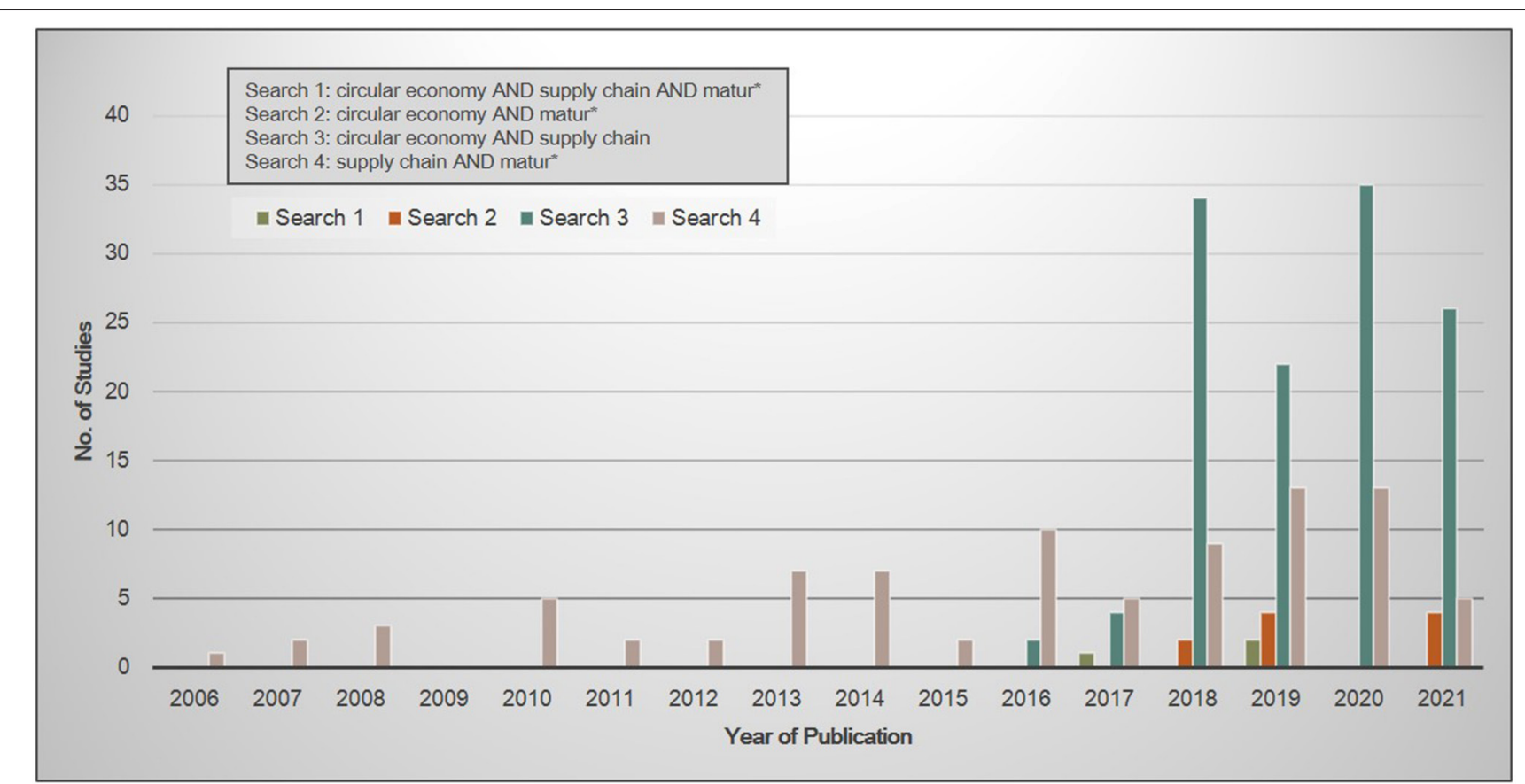

FIGURE 5 | Distribution per year.

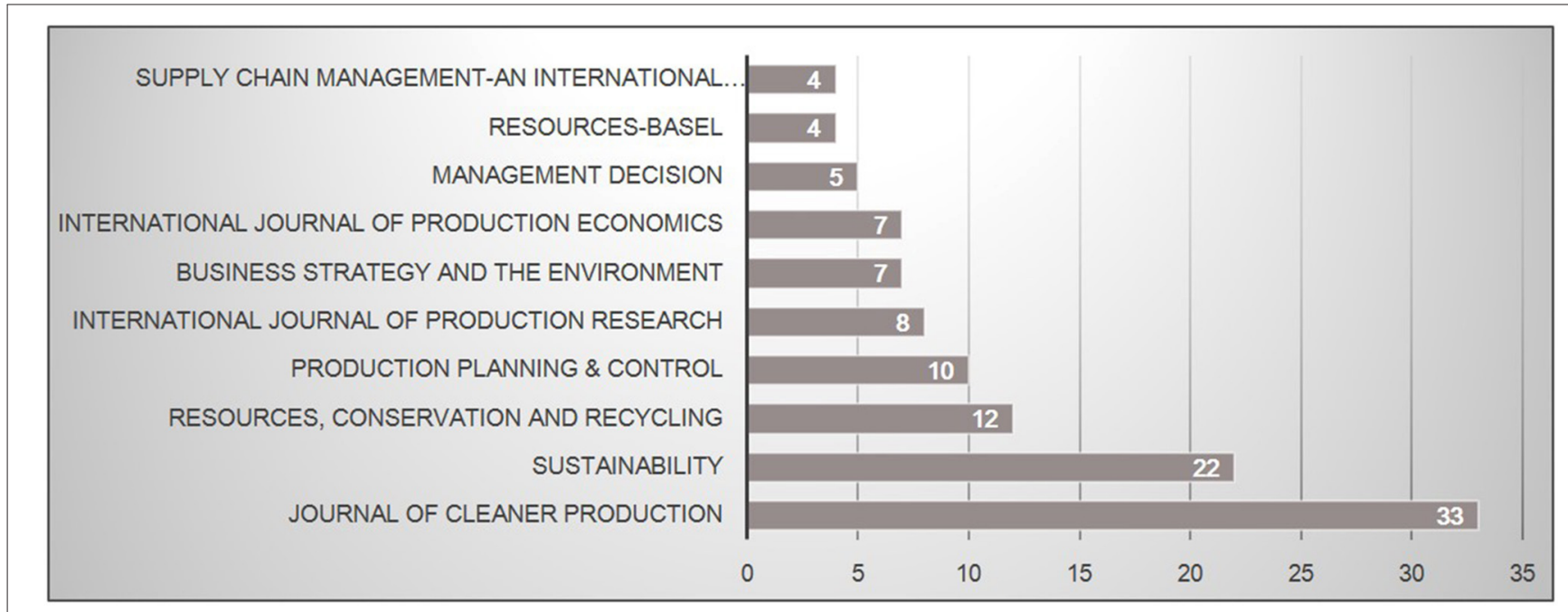

FIGURE 6 | Distribution per source title (top 10).

circular economy elements were identified from the studies' various sections, such as theoretical background, definitions, and conceptualizations as well as proposals, results, and conclusions. The last column indicates whether and, if so, how many indicators were found within the studies.

Of all the elements that were proposed, the R-imperatives is the only one that is encountered in all studies, although with varying depth and scope. For example, in the study of Vegter et al. (2020) the R-imperatives reuse, remanufacture, refurbish and recycle are included in the newly defined SCOR process recover.
In González-Sánchez et al. (2020) study, the R-Imperatives remanufacture, reuse, repair, refurbish and recycle are core elements of the reverse logistics as a fundamental dimension of the circular supply chain. Jain et al. (2018) only include three R-Imperatives, i.e., reuse, remanufacture and recycle.

Although the following four archetypal elements in Table 2 do not appear in all studies analyzed, they do were identified in the majority of the studies, indicating a clear consensus on how the circular economy and circular supply chain is perceived. With regard to the sustainability framework, 16 studies contain 
elaborations on this archetypal element, however, mostly only on the environmental and economic perspective, neglecting the social sustainability. Kravchenko et al. (2019) conduct a literature review on circular economy initiatives and analyze sustainability-related performance indicators. A main result is that environmental indicators dominate over economic and social ones, showing a clear asymmetry between the triple bottom line of sustainability.

Of all archetypal elements, the paradigm shift is the one the least represented in the subset. Only five of the circular economy focused studies indicate some consideration of this element; none of the papers focused on circular maturity do so. Jain et al. (2018) is one example conceptualizing a circular supply chain framework as a new paradigm, implicating that the transition to circularity will require major changes for the product design, the business model and the supply chain management and thus, on all hierarchical levels.

The number of proposed indicators vary from a single index, consisting of 4 dimensions and 17 sub-indicators, assessing the level of sustainability and circularity of manufacturing companies (Azevedo et al., 2017) to the proposition of 45 circular strategies, collected in a circular economy implementation database (Kalmykova et al., 2018).

The second thematic group, dealing with the concept of maturity and the identification of maturity levels, contains 19 studies that went through a complete reading and systematization. This group can be further split into two subgroups: twelve studies focus on the maturity aspects of various supply chain attributes, while the second group of seven studies is somewhat loosely related to the circular economy. Three of the studies considered (Estampe et al., 2013; Correia et al., 2017; Cheshmberah and Beheshtikia, 2020) are SLRs collecting, summarizing, and critically evaluating available maturity models that are not already included in the set of literature. Among the studies presented in these systematic reviews, 11, 11, and 3 studies were selected as sufficiently relevant models for this work in accordance with the same criteria as previously. Thus, there are 41 paper available dealing with the assessment of maturity to some extent. All 41 studies were systematized with respect to the maturity assessment specifications outlined in subsection Maturity Assessment.

There are major differences in the maturity type to be measured within the considered studies. The objectives of the maturity models cover supply chain operations, quality management, sustainability, Industry 4.0 or circular economy at very different levels of detail.

The maturity scope of the papers considered predominantly comes down to either the processes, the company or the network. Only a few studies that focus on quality, sustainability or circularity consider products. Noteworthy among these are the studies of Cooper et al. (1997), EFQM (2010), Garcia Reyes and Giachetti (2010), Almeida Santos et al. (2020), and
Sacco et al. (2021) providing the most extensive maturity scope and thus the greatest aptitude for application in the context of the circular economy. Almeida Santos et al. (2020) outline that existing maturity models are superficial and do not include in detail the elements necessary to measure the level of maturity in sustainability. Consequently, their maturity model includes the product, the company, and the network. The GSCF (Cooper et al., 1997) model focuses on processes that link the supply chain and on the physical flow of goods among members of a supply chain. It is implemented through three primary elements, the supply chain network structure, the supply chain business processes, and the products. The EFQM model for Business Excellence is a business model that provides a holistic view of organizations. The extended system distinguishes nine criteria consisting of five prerequisites (enablers) and four result criteria (results). Both components are weighted at $50 \%$ each. The enablers cover all four dimensions product, process, company and network. Garcia Reyes and Giachetti (2010) develop the supply chain maturity model $\mathrm{S}(\mathrm{CM}) 2$, that describes supply chain maturity across multiple competency areas. The seven competency areas suppliers, production, inventory customers, $\mathrm{HR}$, Information systems and technology management and performance management systems cover the dimensions process, company, and network. Sacco et al. (2021) present the Circularity and Maturity Firm-Level Assessment tool (CM-FLAT) as a comprehensive framework of factors and organizational areas affecting the introduction of the circular economy. The researchers highlight a low adoption of circular practices by most studies and practitioners. To simplify the first interaction of companies with circular economy a radar chart with 15 axes is proposed. The 15 categories measuring company's circularity comprise elements like strategy and vision, supplier selection, waste management and post sales service. Products, processes, and the organization are addressed. With regard to the network, only the procedure for selecting suitable suppliers is considered.

The typology of the maturity models, the arrangement of the individual elements, is predominantly designed as a maturity grid or questionnaire. While 15 of the studies considered suggest a maturity grid and 13 a questionnaire, only 5 studies advocate the use of a structured model.

The number of proposed maturity levels varies between 3 and 6 , or 0 and $100 \%$. This substantiates Fraser et al.'s (2002) statement that the number of maturity levels is in many cases arbitrary and merely calls for a sufficiently discriminating description of the levels. However, eight of the studies considered do not describe the levels in this manner.

Although the descriptors represent the final interpretation of the maturity model, many of them are generic and refer mainly to the five levels introduced by Lockamy and McCormack (2004): Ad-hoc, Defined, Linked, Integrated, and Extended. Using this as a starting point, the descriptors or number of levels are varied slightly among the considered studies. 


\section{DEVELOPMENT OF A MATURITY FRAMEWORK IN THE CIRCULAR SUPPLY CHAIN CONTEXT}

\section{Circular Supply Chain Maturity Dimensions and Sub-Dimensions}

Six elements have been identified as the fundamental basis of the circular economy. These elements, introduced separately in subsection Circular Economy Concept, have a cause-effect relationship that can be used to develop a maturity grid that assesses the circular maturity. Since circular supply chains strive for sustainability, the element sustainability represents the overarching objective of the circular economy. Various challenges along the different lifecycle phases and among different supply chain actors arise by transforming to a circular supply chain, requiring a systemic and holistic thinking (Bressanelli et al., 2018). Holism is achieved through consideration of the strategic, tactical and operational planning level (Homrich et al., 2018). Each of these planning levels is operationalized via an element describing circular economy, so that the maturity of circular economy implementation in the supply chain is hierarchically decomposed and broken down into sub-problems. Strategic decisions were made and capabilities were set by the organization. Both decision making and capability development require a paradigm shift to ensure successful implementation of circular economy principles. The paradigm shift is required at the management level (intangible assets) as well as at the information and technology level (tangible assets). On the tactical level decisions with respect to products were made. The element value focus corresponds with offering value to customers through products and services. The creation of the value at the beginning, middle, and end of the products' life cycle is considered. On the operational level the processes operationalize the circular economy elements R-imperatives as well as restorative and regenerative cycles. The circular economy offers numerous retention options that lead to a disruptive change in processes. The key processes of a supply chain in a circular economy are considered.

These elements are arranged in a three-layered maturity grid, as shown in Figure 7. The application of a maturity grid is indicated, since it allows a decomposition of the objective into subproblems, while a more formal representation is impossible due to relationships that cannot be clearly formalized as a structured model (Correia et al., 2017). A first decomposition includes the first layer of the maturity framework-the circular maturity dimensions organization, products, and processes. Within the second decomposition these dimensions are segregated as the second layer into the so-called circular maturity sub-dimensions. The third decomposition, and thus the third level, comprises the circular maturity indicators, which qualitatively describe the circular supply chain characteristics corresponding to the maturity level. The following Subchapters 5.11 provide details on the circular supply chain dimensions and subdimensions as well as on the proposed maturity levels (Subchapter 5.2).

\section{Organization (Strategic)}

On the strategic level, fundamental decisions about longterm strategies and resources required to implement these are made (Steven, 2019). Consequently, the first circular maturity dimension, organization, plays a significant role in shaping the subsequent dimensions as well as in implementation from planning to execution. The proposed sub-dimensions of circular maturity within this first dimension therefore focus on managerial and informational/technological requirements. These two sub-dimensions are decisive factors for the success of the transition from a linear to a circular supply chain.

- Management: This dimension includes all critical success factors that can be allocated on a supporting capability level, e.g., foresight, vision, and understanding of the circular supply chain concept and its implications, leadership/top management support for circular economy adoption, supportive participation of all supply chain stakeholders and an effective planning and management of circular supply chain requirements and its evolutionary implications (Frederico et al., 2019; Sehnem et al., 2019b; Yadav et al., 2020).

- Information/Technology: Information systems and (digital) technologies are anticipated to support the transition to a more circular supply chain on a large scale (Nascimento et al., 2019). Thus, innovative digital practices such as big data analytics, data management and constant material tracking should be implemented for the initial development of the circular supply chain, but also for the further ongoing development (Frederico et al., 2019). An appropriate IT infrastructure and an effective information management system enable the supply chain's circular transition on subsequent hierarchy levels.

\section{Products (Tactical)}

On the tactical level, mid-term decisions on the effective and efficient use of available resources have to be made (Anthony, 1981). In the context of the circular economy, the product becomes the focus of decision-making at this level of hierarchy (Jain et al., 2018). Thus, adapting the management of the product's lifecycle is an essential component to make the linear supply chain more circular. We propose to combine the productcentric lifecycle phases-beginning of life (BOL), middle of life (MOL), and end of life (EOL) - with (newly conceptualized) value dimensions.

- BOL-Value Creation: Within the BOL, several phases of the product take place, i.e., product research, design and development, procurement, and production, all of which are geared toward the goal of (circular) value creation. This includes circular product design, that allows for slowing and closing of resource loops (Bocken et al., 2016). Products need to be designed for durability as well as upgradability and repair. The procurement has to focus on suppliers that also engage in the transformation toward circularity, hence, on those who substitute materials by recycled or bio-based ones, produce at a lower environmental impact and are open for cross-sectional collaboration (Kalmykova et al., 2018). 


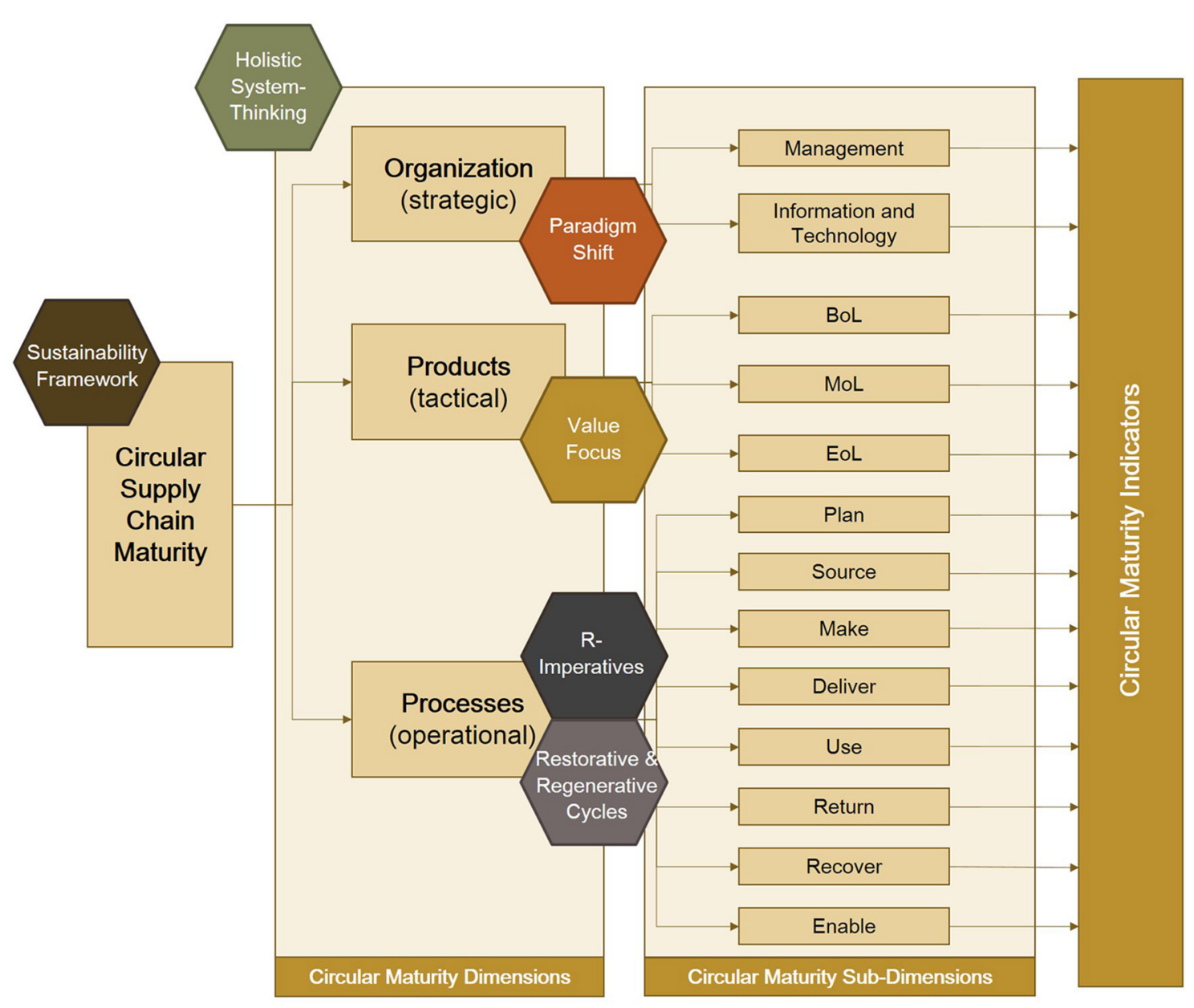

FIGURE 7 | Circular supply chain maturity - conceptualization.

The production itself should provide value with reduced energy and pure, non-toxic inputs, and thus increasing material productivity (Ellen MacArthur Foundation, 2015)

- MOL-Value Retention: The MOL includes the phases packaging and storage, distribution and product transport, product use as well as service and product support. Several value retention mechanisms are to be addressed within this lifecycle, such as dematerialized and reusable packaging, product-service options, take-back- and trade-in-options as well as upgrade, maintenance and reuse options, resulting in a high product use intensity (Kalmykova et al., 2018; Montag and Steven, 2021).

- EOL-Value Extension: The EOL is the key to closing the loop after the consumer no longer uses the product. The product collection, sorting and recycling phases must be implemented efficiently so that the existing product value can be extended. This includes building a (reverse) logistics infrastructure that ensures cost-effective take-back and efficient collection, sorting and separation, especially with regard to biological and technical nutrients. The ultimate goal is to achieve a $100 \%$ product return rate in order to be able to implement the R-Imperative processes at the operational level.

\section{Processes (Operational)}

To structure supply chain management processes, several business process frameworks have been developed (Hewitt, 1994; Cooper et al., 1997). For obtaining a holistic view of supply chain management processes, we decided to use an overarching framework. The framework chosen for such a holistic approach is the Supply Chain Operations Reference (SCOR) model (Poluha, 2007) which is considered as the standard framework for supply chains by practitioners and academics. The SCOR model consists of processes on three hierarchical levels: Level 1 contains the six distinct management processes plan, source, make, deliver, return, and enable (SCOR, 2012). Those management processes are further decomposed into process categories on level 2 and process elements on level 3 of the SCOR model.

Overall, the model enables the description of processes in supply chains, as is also shown by its frequent use in practice. This promotes the overcoming of boundaries between functionally oriented corporate divisions as well as between different companies in a supply chain. Thus, the supply chain is supported in the definition, design, and implementation of supply chain processes. Like many other model approaches, the SCOR model 
is limited to description and does not include explanatory statements. In addition, the process hierarchy essentially refers to individual companies in the supply chain. The cross-company character is only achieved by linking the company-related model specifications. Beyond the ongoing further development, there are individual proposals for change. For example, the extension of the SCOR model to include processes could lead to an increase in benefits.

Vegter et al. (2020) applies Level 1 SCOR processes to circular supply chains and also adds the three processes "use," "recover," and "enable":

- The process plan balances supply chain requirements and available supply chain resources and assets (APICS, 2017). A circular business approach calls for supply chains to consider environmental limits, such as the assimilative capacity of the environment and the extraction of resources vs. their returns (Boulding, 1966; Pearce et al., 1990; Vegter et al., 2020).

- The purpose of the process source is to schedule product deliveries, receive, and inspect the product, transfer it, and approve payment to the supplier (APICS, 2017). The supply chain in the circular economy focuses on alternative materials that have a lower environmental impact. The materials can be easily returned, disassembled, and recycled (Farooque et al., 2019).

- The process make focuses on the planning of production activities (APICS, 2017). Thus, this process also comprises the packaging and waste management (APICS, 2017), which are central sub-processes in circular economy.

- The process deliver not only focuses on shipping products to end users, but also on the organization of the delivery of spare parts for maintenance during the use of the product to extend their life (Kalmykova et al., 2018).

- The process use comprises the process of using the product by the customer and the process required to retain and restore the product for fulfillment of its function (Kothamasu et al., 2006).

- Return describes the process of collecting and delivering products after end-of-life need to a facility for waste processing and recovery. End-users were seen as a source of products. Thus, companies need to develop buy back and take backprograms (Jain et al., 2018; Kalmykova et al., 2018).

- The process recover comprises the recovery processes reuse, remanufacturing, refurbishing, upcycling, recycling and downcycling (Jain et al., 2018).

- As the management of a supply chain is faced with the challenges of circular economy (Prieto-Sandoval et al., 2018) the process enable focuses in the communication with organizations and customers. This overarching process includes, for example, the traceability of material flows.

\section{Circular Supply Chain Maturity Framework}

In this subsection, the circular supply chain maturity framework is proposed. Figure $\mathbf{8}$ shows this framework, which is based on the previously conceptualized circular supply chain maturity. The developed circular maturity dimensions-organization, products, processes-therefore form the three blocks that define the supply chain's maturity. It should be noted that the proposed framework-although based on the previously deductively derived circular maturity conceptualization-follows a qualitative strategy and thus provides information at a qualitative and therefore more abstract level, focusing on the first layer of the circular maturity conceptualization. More quantitative measures and indicators will be integrated into the second and third levels in future studies, building on the current results.

The framework's typology is a maturity grid, consisting of five maturity levels: 0 -linear, 1-minimal, 2-developing, 3defined, and 4-circular. The maturity scale was developed following Bibby and Dehe (2018) who have suggested a maturity model for assessing Industry 4.0 with four different maturity levels (minimal, developing, defined, excellence). Within our research, Bibby and Dehe's scale was modified in two places. For once, a preceding maturity level 0 was added, covering all fully linear supply chains. The actual circular maturity path is initiated at level 1 , where minimal circularity at supply chain level is achieved. Level 2 and 3 form the intermediate maturity levels, where further efforts concerning the circular economy implementation are realized, however, still there is still potential for the transformation. They can be categorized as level of improvements (Frederico et al., 2019). A second modification is the level descriptor of the highest maturity level. For our framework this maturity level is called circular, indicating that at this maturity level the supply chain reached the ideal state of full circularity.

As it is shown in Figure 8, for each circular dimension in each maturity level, this research has established quantitative circular maturity indicators, describing the characteristics of circular maturity in the corresponding dimension and maturity level. At the linear level, the circular dimensions are nearly nonexistent as circularity is not a part of the supply chain, neither on a strategic nor on a tactical or operational level. The circular maturity dimension and the corresponding sub-dimensions are characterized by linearity. At the initial maturity level, efforts on supply chain circularity are rare and just intentional. For instance, the supply chain's organization has not yet experienced a paradigm shift in management and information systems, thus leading to a minimal adoption of circularity. The same applies to the other two circular dimensions: products have only a minimal degree of circularity and only a few R-imperatives were implemented in the supply chain's processes. The following two maturity levels can be described as stages of improvement (Frederico et al., 2019), leading from a minimally circular to a fully circular supply chain. At the developing level, circularity is already a part of the supply chain and partially embedded in organization, products, and processes. In supply chains with the defined maturity level, circular economy is highly embedded and thus, many efforts on circularity are realized. Within the process dimension, for example, the majority of the eight SCOR processes were fully redesigned, aiming to close the loop. Both the restorative and regenerative cycle are clearly defined. The final level of maturity and thus the goal on the path to a fully circular supply chain is characterized by a comprehensive and holistic adoption of the principles of the circular economy in all dimensions. Circularity has the highest priority in organization, 


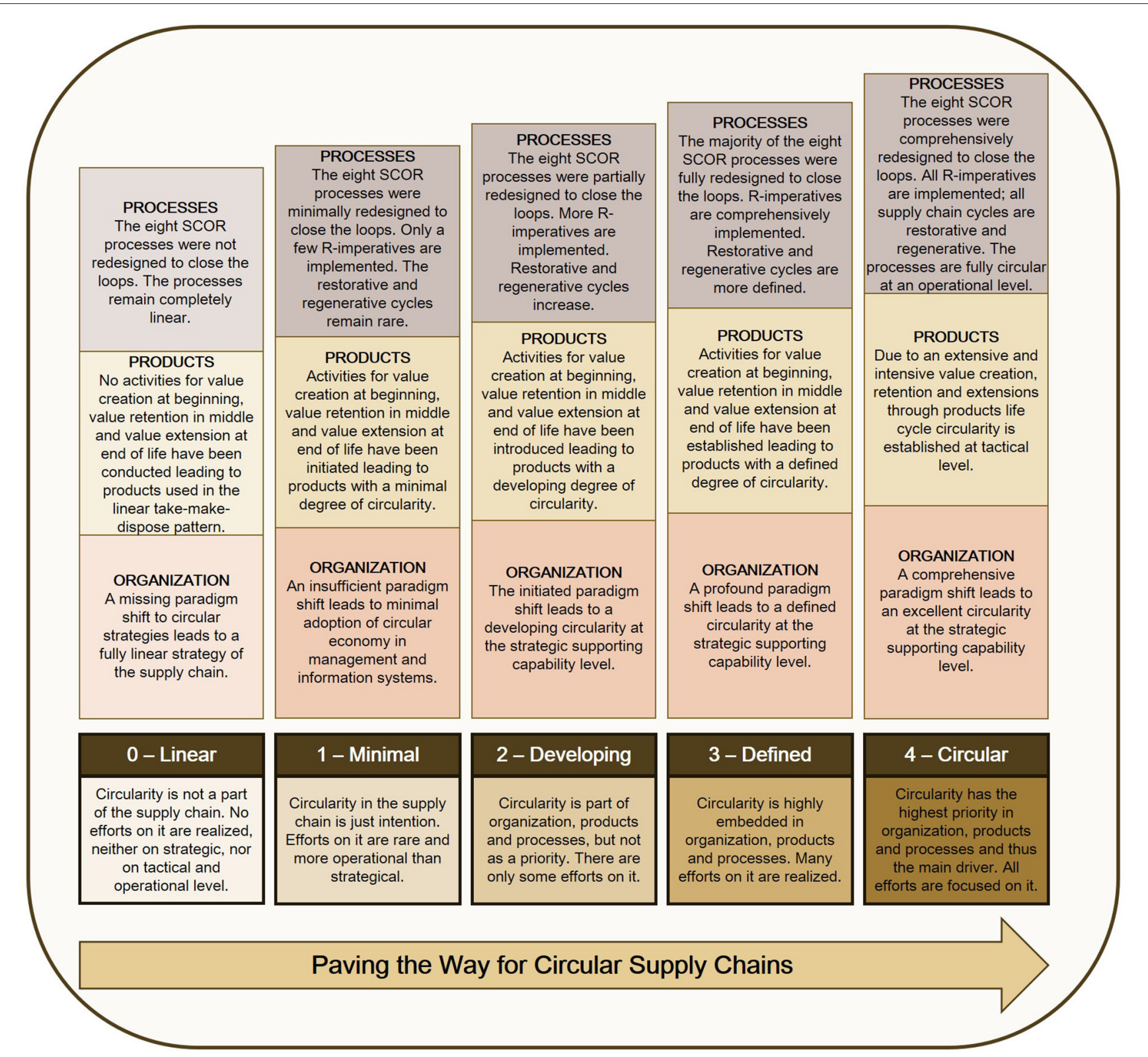

FIGURE 8 | Circular supply chain maturity framework.

for products and in all processes. A matured circular supply chain has experienced a paradigm shift at the organizational level, applies extensive and intensive value creation, retention and extension on the product level and comprehensively redesigned its processes so that all loops are closed and R-imperatives implemented. All the supply chain's efforts are strongly focused on circularity.

The circular supply chain maturity framework is a conceptual proposition obtained through a SLR on circular economy, supply chain management and maturity assessment. The dimensions identified and as circular supply chain maturity conceptualized provide robust building blocks for understanding the current level of maturity of supply chains adopting the circular economy principles. The framework proposed here is intended to serve as a guide for supply chains seeking to move toward a circular supply chain. Thus, the circular supply chain maturity framework serves as roadmap for the circular economy implementation at supply chain level.

\section{CONCLUSION, LIMITATIONS, AND FUTURE RESEARCH OPPORTUNITIES}

For theory, there is a need to systematize and understand the circularity that is increasing in companies and supply chains. This establishes the groundwork for a subsequent causal relationship 
between circular economy practices and sustainable objectives. For practice, there is a need to quantify achievements and to be able to evaluate specific endeavors with respect to sustainable objectives. This work, of exploratory and theoretical character, strives for a status quo assessment of supply chains circularity in the light of company-specific as well as societal goals of sustainable development. This is to empower supply chains to develop an individual roadmap to an individually targeted level of circularity: How to progress from linear to circular? However, an exhaustive and in-depth literature analysis discloses that this ambition must be preceded by an overarching research question: How to conceptualize the maturity of circular economy implementation at supply chain level?

The maturity framework successively developed here from the principles of circular economy and a SLR creates a navigation tool to trace the supply chain's individual path of a transformation from linear to circular economy. It aims to deliver a roadmap for circular supply chain transformation, supporting the gradual circular economy adoption.

The proposed model needs to be further operationalized via quantitative indicators on the third layer (circular maturity indicators). Furthermore, a pilot application is required in a wide variety of companies in terms of size and type of goods produced, in order to suit all types of companies in the greatest possible extent. After successful application of this framework, insights gained can be used to elaborate it into a structured model that considers the interdependencies at the different layers of the framework. For instance, it seems plausible that a supply chain with a sophisticated circular strategy has already achieved circular progress at the tactical level as well. Contemporary supply chains are often regarded as decentrally controlled networks without a focal company. This significantly complicates the assessment of circularity. The framework developed here aims at a selfdetermination by a focal company, so that an adaptation of the assessment method can be beneficial. A weighting of the individual dimensions may be expert-based. It is conceivable, for instance, that the operational level has a stronger and more proximate influence on the degree of circularity than the strategic level.

\section{REFERENCES}

Aberdeen Group (2006). The Supply Chain Visibility Roadmap - Moving from vision to True Business Value. Boston, MA: Aberdeen Group.

Accenture (2012). How to Understand and Use the Key Drivers and Trends in Today's Pharmaceutical Markets? Accenture Management Consulting.

Almeida Santos, D. de, Luiz Gonçalves Quelhas, O., Francisco Simões Gomes, C., Perez Zotes, L., Luiz Braga França, S., Vinagre Pinto de Souza, G., et al. (2020). Proposal for a maturity model in sustainability in the supply chain. Sustainability 12:9655. doi: 10.3390/su12229655

Angelis, R. de, Howard, M., and Miemczyk, J. (2018). Supply chain management and the circular economy: towards the circular supply chain. Production Plann. Control 29, 425-437. doi: 10.1080/09537287.2018.1449244

Anthony, R. N. (1981). Planning and Control Systems: A Framework for Analysis. Boston, MA: Harvard University Press.

APICS (2017). Supply Chain Operations Reference Model SCOR. Version 12.0. Available online at: http://www.apics.org/docs/default-source/scor-training/ scor-v12-0-framework-introduction.pdf?sfvrsn $=2$
Circular supply chains contribute holistically to sustainable development, as shown above, although there are immediate effects in the ecological dimension that then spill over into the economic and social dimensions. These domino-like knock-on effects, as shown in Figure 2, could be given attention in future research. The maturity level assessment is the baseline for the development of supply chain individual roadmaps. A catalog of actions depending on the maturity level will increase the tools value for practitioners.

As van Houten-Chief Executive Officer of the electronic company Philips-stated, the shift from a linear to a circular economy "[...] will be a tumultuous one [...], like all major transitions in human history. It will feature heroes and pioneers, naysayers and obstacles, and moments of victory and doubt." Supply chains need appropriate tools, such as the circular supply chain maturity framework developed here, to claim victory. At the very least, as the Sixth Assessment Report of the IPCC demonstrated, society will benefit from any circular maturation of supply chains.

\section{DATA AVAILABILITY STATEMENT}

The original contributions presented in the study are included in the article/supplementary material, further inquiries can be directed to the corresponding author/s.

\section{AUTHOR CONTRIBUTIONS}

LM and TK designed the research model, conceptualized the proposed framework and wrote the manuscript. MS provided feedback and supervised the research project. All authors contributed to the article and approved the submitted version.

\section{FUNDING}

The authors acknowledge support by the Open Access Publication Funds of the Ruhr-Universität Bochum.

Azevedo, S., Godina, R., and Matias, J. (2017). Proposal of a sustainable circular index for manufacturing companies. Resources 6:63. doi: 10.3390/resources6040063

Babin, R., and Nicholson, B. (2011). How green is my outsourcer? Measuring sustainability in global IT outsourcing. Strat. Outs. 4, 47-66. doi: $10.1108 / 17538291111108426$

Batista, L., Bourlakis, M., Smart, P., and Maull, R. (2018). In search of a circular supply chain archetype - a content-analysis-based literature review. Production Plann. Control 29, 438-451. doi: 10.1080/09537287.2017.1343502

Bibby, L., and Dehe, B. (2018). Defining and assessing industry 4.0 maturity levels - case of the defence sector. Production Plann. Control 29, 1030-1043. doi: 10.1080/09537287.2018.1503355

Blasi, S., Crisafulli, B., and Sedita, S. R. (2021). Selling circularity: understanding the relationship between circularity promotion and the performance of manufacturing SMEs in Italy. J. Clean. Prod. 303:127035. doi: 10.1016/j.jclepro.2021.127035

Bocken, N. M. P., Pauw, I. de, Bakker, C., and van der Grinten, B. (2016). Product design and business model strategies for a circular economy. 
J. Indus. Production Eng. 33, 308-320. doi: 10.1080/21681015.2016.11 72124

Boulding, K. E. (1966). "The economics of the coming spaceship earth," in Environmental Quality in a Growing Economy, ed H. Jarrett (Baltimore, MD: Johns Hopkins University Press), 3-14.

Bracquené, E., Dewulf, W., and Duflou, J. R. (2020). Measuring the performance of more circular complex product supply chains. Resources Conserv. Recycl. 154:104608. doi: 10.1016/j.resconrec.2019.104608

Bressanelli, G., Perona, M., and Saccani, N. (2018). Challenges in supply chain redesign for the circular economy: a literature review and a multiple case study. Int. J. Production Res. 57, 7395-7422. doi: 10.1080/00207543.2018.1542176

Bruin, T. de, Rosemann, M., Freeze, R., and Kaulkarni, U. (2005). "Understanding the main phases of developing a maturity assessment model," in Proceedings of the 16th Australasian Conference on Information Systems (ACIS 2005), eds D. Bunker, B. Campbell, and J. Underwood (Sydney, NSW), 8-19.

Cheshmberah, M., and Beheshtikia, S. (2020). Supply chain management maturity: an all-encompassing literature review on models, dimensions and approaches. LogForum 16, 103-116. doi: 10.17270/J.LOG.2019.377

Çinar, Z. M., Zeeshan, Q., and Korhan, O. (2021). A framework for industry 4.0 readiness and maturity of smart manufacturing enterprises: a case study. Sustainability 13:6659. doi: 10.3390/su13126659

Cooper, M., Lambert, D., and Pagh, J. (1997). Supply chain management: more than a new name for logistics. Int. J. Logistics Manage. 8, 1-14. doi: 10.1108/09574099710805556

Correia, E., Carvalho, H., Azevedo, S., and Govindan, K. (2017). Maturity models in supply chain sustainability: a systematic literature review. Sustainability 9:64. doi: $10.3390 /$ su9010064

Cristoni, N., and Tonelli, M. (2018). Perceptions of firms participating in a circular economy. EJSD 7, 105-118. doi: 10.14207/ejsd.2018.v7n4p105

Denyer, D., and Tranfield, D. (2009). "Producing a systematic review," in The SAGE Handbook of Organizational Research Methods, eds D. A. Buchanan, and A. Bryman (Thousand Oaks, CA: Sage Publications Inc), 671-689.

Edgeman, R., and Eskildsen, J. (2014). Modeling and assessing sustainable enterprise excellence. Bus. Strat. Env. 23, 173-187. doi: 10.1002/bse.1779

EFQM (2010). EFQM: Excellence Model. Available online at: https://www.efqm. org/efqm-model

Ellen MacArthur Foundation (2013). Towards the Circular Economy, Vol. 1. Available online at: https://www.ellenmacarthurfoundation.org/publications/ towards-the-circular-economy-vol-1-an-economic-and-business-rationalefor-an-accelerated-transition (accessed July 07, 2020).

Ellen MacArthur Foundation (2015). Towards a Circular Economy: Business Rationale for an Accelerated Transition. Available online at: https://www. ellenmacarthurfoundation.org/publications/towards-a-circular-economybusiness-rationale-for-an-accelerated-transition (accessed July 06, 2020).

Ellen MacArthur Foundation (2017). What is the Circular Economy? Available online at: https://www.ellenmacarthurfoundation.org/circular-economy/whatis-the-circular-economy (accessed July 10, 2020).

Estampe, D., Lamouri, S., Paris, J.-L., and Brahim-Djelloul, S. (2013). A framework for analysing supply chain performance evaluation models. Int. J. Production Econ. 142, 247-258. doi: 10.1016/j.ijpe.2010.11.024

Farooque, M., Zhang, A., Thürer, M., Qu, T., and Huisingh, D. (2019). Circular supply chain management: a definition and structured literature review. J. Clean. Production 228, 882-900. doi: 10.1016/j.jclepro.2019.04.303

Favre Bertin, M., and Estampe, D. (2004). Le metier de supply chain manager. Logistique Manage. 12, 83-91. doi: 10.1080/12507970.2004.11516801

Ferreira, I., Castro Fraga, M. de, Godina, R., Souto Barreiros, M., and Carvalho, H. (2019). A proposed index of the implementation and maturity of circular economy practices-the case of the pulp and paper industries of Portugal and Spain. Sustainability 11:1722. doi: 10.3390/su11061722

Ferreira, M. A., Jabbour, C. J. C., and de Sousa Jabbour, A. B. L. (2017). Maturity levels of material cycles and waste management in a context of green supply chain management: an innovative framework and its application to Brazilian cases. J. Mater. Cycles Waste Manag. 19, 516-525. doi: 10.1007/s10163-015-0416-5

Fraser, P., Moultrie, J., and Gregory, M. (2002). “The use of maturity models/grids as a tool in assessing product development capability," in IEEE International Engineering Management Conference (Cambridge: IEEE), 244-249.
Frederico, G. F., Garza-Reyes, J. A., Anosike, A., and Kumar, V. (2019). Supply chain 4.0: concepts, maturity and research agenda. SCM 25, 262-282. doi: 10.1108/SCM-09-2018-0339

Garcia Reyes, H., and Giachetti, R. (2010). Using experts to develop a supply chain maturity model in Mexico. Supp. Chain Manage. 15, 415-424. doi: $10.1108 / 13598541011080400$

Garcia, H. (2008). A capability maturity model to assess supply chain performance. FIU Electronic Theses Dissertations 191. doi: 10.25148/etd.FI10022514

Geisendorf, S., and Pietrulla, F. (2018). The circular economy and circular economic concepts-a literature analysis and redefinition. Thunderbird Int. Bus. Rev. 60, 771-782. doi: 10.1002/tie.21924

Geissdoerfer, M., Pieroni, M. P., Pigosso, D. C., and Soufani, K. (2020). Circular business models: a review. J. Cleaner Production 277:123741. doi: 10.1016/j.jclepro.2020.123741

Geissdoerfer, M., Savaget, P., Bocken, N. M., and Hultink, E. J. (2017). The circular economy - a new sustainability paradigm? J. Cleaner Production 143, 757-768. doi: 10.1016/j.jclepro.2016.12.048

Geng, Y., and Doberstein, B. (2008). Developing the circular economy in China: challenges and opportunities for achieving 'leapfrog development'. Int. J. Sustain. Dev. World Ecol. 15, 231-239. doi: 10.3843/SusDev.15.3:6

Genovese, A., Acquaye, A. A., Figueroa, A., and Koh, S. L. (2017). Sustainable supply chain management and the transition towards a circular economy: evidence and some applications. Omega 66, 344-357. doi: 10.1016/j.omega.2015.05.015

Golinska, P., and Kuebler, F. (2014). The method for assessment of the sustainability maturity in remanufacturing companies. Procedia CIRP 15, 201-206. doi: 10.1016/j.procir.2014.06.018

Golinska-Dawson, P., Werner-Lewandowska, K., and Kosacka-Olejnik, M. (2021). Responsible resource management in remanufacturing-framework for qualitative assessment in small and medium-sized enterprises. Resources 10:19. doi: 10.3390/resources10020019

González-Sánchez, R., Settembre-Blundo, D., Ferrari, A. M., and García-Muiña, F. E. (2020). Main dimensions in the building of the circular supply chain: a literature review. Sustainability 12:2459. doi: 10.3390/su12062459

Gorecki, J. (2019). Circular economy maturity in construction companies. IOP Conf. Ser. Mater. Sci. Eng. 471:112090. doi: 10.1088/1757-899X/471/11/112090

Govindan, K., and Hasanagic, M. (2018). A systematic review on drivers, barriers, and practices towards circular economy: a supply chain perspective. Int. J. Production Res. 56, 278-311. doi: 10.1080/00207543.2017.1402141

Hewitt, F. (1994). Supply chain redesign. Int. J. Logistics Manage. 5, 1-10. doi: 10.1108/09574099410805162

Homrich, A. S., Galvão, G., Abadia, L. G., and Carvalho, M. M. (2018). The circular economy umbrella: trends and gaps on integrating pathways. J. Clean. Production 175, 525-543. doi: 10.1016/j.jclepro.2017.11.064

Howard, M., Hopkinson, P., and Miemczyk, J. (2018). The regenerative supply chain: a framework for developing circular economy indicators. Int. J. Production Res. 57, 7300-7318. doi: 10.1080/00207543.2018. 1524166

Hynds, E. J., Brandt, V., Burek, S., Jager, W., Knox, P., Parker, J. P., et al. (2014). A maturity model for sustainability in new product development. Res. Technol. Manage. 57, 50-57. doi: 10.5437/08956308X5701143

IBM (2005). Follow the Leaders - Scoring High on the Supply Chain Maturity Model. Somers, NY: IBM Business Consulting. Available online at: http://web.nchu. edu.tw/ pfsum/SCM/2006_IBM_Supply_Chain_Maturity_Model.pdf

ING (2018). Opportunity and Disruption: How Circular Thinking Could Change US Business Models - A Circular Economy Survey. Available online at: https://www.ing.com/MediaEditPage/Opportunity-and-disruptionHow-circular-thinking-could-change-US-business-models.htm

IPCC (2021). Climate Change 2021, Sixth Assessment Report. Available online at: https://www.ipcc.ch/report/ar6/wg1/downloads/report/IPCC_AR6_WGI_ Full_Report.pdf (accessed August 29, 2021).

Jain, S., Jain, N. K., and Metri, B. (2018). Strategic framework towards measuring a circular supply chain management. Benchmarking 25, 3238-3252. doi: 10.1108/BIJ-11-2017-0304

Jaklič, J., Peter, T., Ales, G., and Stemberger, M. (2006). Enhancing lean supply chain maturity with business process management. J. Information Org. Sci. $30,205-223$. 
Jia, F., Yin, S., Chen, L., and Chen, X. (2020). The circular economy in the textile and apparel industry: a systematic literature review. J. Clean. Production 259:120728. doi: 10.1016/j.jclepro.2020.120728

Kalmykova, Y., Sadagopan, M., and Rosado, L. (2018). Circular economy - from review of theories and practices to development of implementation tools. Resources Conserv. Recycl. 135, 190-201. doi: 10.1016/j.resconrec.2017.10.034

Khan, S., and Haleem, A. (2020). Strategies to implement circular economy practices: a Fuzzy DEMATEL approach. J. Ind. Intg. Manage. 05, 253-269. doi: $10.1142 /$ S2424862220500050

Kirchherr, J., Reike, D., and Hekkert, M. (2017). Conceptualizing the circular economy: an analysis of 114 definitions. Resources Conserv. Recycl. 127, 221-232. doi: 10.1016/j.resconrec.2017.09.005

Korhonen, J., Honkasalo, A., and Seppälä, J. (2018). Circular economy: the concept and its limitations. Ecol. Econ. 143, 37-46. doi: 10.1016/j.ecolecon.2017.06.041

Kothamasu, R., Huang, S., and VerDuin, W. (2006). System health monitoring and prognostics - a review of current paradigms and practices. Int. J. Adv. Manuf. Technol. 28, 1012-1024. doi: 10.1007/s00170-004-2131-6

Kravchenko, M., Pigosso, D. C., and McAloone, T. C. (2019). Towards the ex-ante sustainability screening of circular economy initiatives in manufacturing companies: consolidation of leading sustainability-related performance indicators. J. Clean. Production 241:118318. doi: 10.1016/j.jclepro.2019.118318

Kurnia, S., Rahim, M. M., Samson, D., and Singh, P. J. (2014). "Sustainable supply chain management capability maturity: framework development and initial evaluation," in ECIS 2014 Proceedings: 22th European Conference on Information Systems; Tel Aviv, Israel, June 9-11, 2014, eds M. Avital, J. M. Leimeister, and U. Schultze (AIS Electronic Library), 1-11.

Lahti, M., Shamsuzzoha, A., and Helo, P. (2009). Developing a maturity model for supply chain management. IJLSM 5:654. doi: 10.1504/IJLSM.2009.024796

Lockamy, A., and McCormack, K. (2004). The development of a supply chain management process maturity model using the concepts of business process orientation. Supp. Chain Manage. 9, 272-278. doi: 10.1108/13598540410550019

Loiseau, E., Saikku, L., Antikainen, R., Droste, N., Hansjürgens, B., Pitkänen, K., et al. (2016). Green economy and related concepts: an overview. J. Clean. Production 139, 361-371. doi: 10.1016/j.jclepro.2016.08.024

Lüdeke-Freund, F., Gold, S., and Bocken, N. M. P. (2018). A review and typology of circular economy business model patterns. J. Indus. Ecol. 23, 36-61. doi: $10.1111 /$ jiec. 12763

Mangan, J., Lalwani, C. S., Butcher, T., and Javadpour, R. (2012). Global Logistics and Supply Chain Management. Chichester: Wiley.

Masi, D., Day, S., and Godsell, J. (2017). Supply chain configurations in the circular economy: a systematic literature review. Sustainability 9:1602. doi: $10.3390 /$ su 9091602

Masi, D., Kumar, V., Garza-Reyes, J. A., and Godsell, J. (2018). Towards a more circular economy: exploring the awareness, practices, and barriers from a focal firm perspective. Production Plann. Control 29, 539-550. doi: 10.1080/09537287.2018.1449246

McCormack, K., Bronzo Ladeira, M., and Paulo Valadares de Oliveira, M. (2008). Supply chain maturity and performance in Brazil. Supp. Chain Manage. 13, 272-282. doi: $10.1108 / 13598540810882161$

Merli, R., Preziosi, M., and Acampora, A. (2018). How do scholars approach the circular economy? A systematic literature review. J. Clean. Production 178, 703-722. doi: 10.1016/j.jclepro.2017.12.112

Montag, L. (2021). Circular Economy and Supply Chains: Defintions, Conceptualizations, and Research Agenda of the Circular Supply Chain Framework. Under Review.

Montag, L., and Steven, M. (2021). Ganzheitlich-zirkuläres Product Lifecycle Management - Zirkuläre Strategieentwicklung zur Unterstützung einer klimafreundlichen Produktion. Industrie 4.0 Manage. 37, 12-16.

Morseletto, P. (2020). Restorative and regenerative: exploring the concepts in the circular economy. J. Indus. Ecol. 24, 763-773. doi: 10.1111/jiec. 12987

Murray, A., Skene, K., and Haynes, K. (2017). The circular economy: an interdisciplinary exploration of the concept and application in a global context. J. Bus/ Ethics 140, 369-380. doi: 10.1007/s10551-015-2693-2

Nascimento, D. L. M., Alencastro, V., Quelhas, O. L. G., Caiado, R. G. G., GarzaReyes, J. A., Rocha-Lona, L., et al. (2019). Exploring Industry 4.0 technologies to enable circular economy practices in a manufacturing context. JMTM 30, 607-627. doi: 10.1108/JMTM-03-2018-0071
Okongwu, U., Morimoto, R., and Lauras, M. (2013). The maturity of supply chain sustainability disclosure from a continuous improvement perspective. Int. J. Productivity Perf. Manage. 62, 827-855. doi: 10.1108/IJPPM-02-2013-0032

Pearce, D. W., Turner, R. K., and Pearce, D. W. (1990). Economics of natural Resources and the Environment. Harlow: Pearson Education.

Pigosso, D. C., Rozenfeld, H., and McAloone, T. C. (2013). Ecodesign maturity model: a management framework to support ecodesign implementation into manufacturing companies. J. Clean. Production 59, 160-173. doi: 10.1016/j.jclepro.2013.06.040

Piwowar-Sulej, K., Krzywonos, M., and Kwil, I. (2021). Environmental entrepreneurship - bibliometric and content analysis of the subject literature based on H-Core. J. Clean. Production 295:126277. doi: 10.1016/j.jclepro.2021.126277

Poluha, R. G. (2007). Anwendung des SCOR-Modells zur Analyse der Supply Chain: Explorative empirische Untersuchung von Unternehmen aus Europa, Nordamerika und Asien. Zugl. Köln, Univ., Diss., 2005 u.d.T. Poluha, Rolf G. Analyse der Supply Chain von Unternehmen mittels des Supply Chain Operations Reference (SCOR)-Modells. Lohmar: Eul.

Potting, J., Hekkert, M., Worrell, E., and Hanemaaijer, A. (2017). Circular Economy: Measuring Innovation in the Product Chain. The Hague: PBL Netherlands Environmental Assessment Agency.

Prieto-Sandoval, V., Jaca, C., and Ormazabal, M. (2018). Towards a consensus on the circular economy. J. Clean. Production 179, 605-615. doi: 10.1016/j.jclepro.2017.12.224

Pullen, W. (2007). A public sector HPT maturity model. Perf. Improv. 46, 9-15. doi: $10.1002 /$ pfi.119

Reefke, H., Ahmed, M. D., and Sundaram, D. (2014). Sustainable supply chain management-decision making and support: the SSCM maturity model and system. Global Bus. Rev. 15, 1S-12S. doi: 10.1177/0972150914550138

Reike, D., Vermeulen, W. J., and Witjes, S. (2018). The circular economy: new or refurbished as CE 3.0? - Exploring controversies in the conceptualization of the circular economy through a focus on history and resource value retention options. Resources Conserv. Recycl. 135, 246-264. doi: 10.1016/j.resconrec.2017.08.027

Richardson, J. (2008). The business model: an integrative framework for strategy execution. Strat. Change 17, 133-144. doi: 10.1002/jsc.821

Robinson, H. S., Anumba, C. J., Carrillo, P. M., and Al-Ghassani, A. M. (2006). STEPS: a knowledge management maturity roadmap for corporate sustainability. BPMJ 12, 793-808. doi: 10.1108/14637150610710936

Sacco, P., Vinante, C., Borgianni, Y., and Orzes, G. (2021). Circular economy at the firm level: a new tool for assessing maturity and circularity. Sustainability 13, 5288. doi: 10.3390/su13095288

Sartori, J., and Frederico, F. (2017). Maturity and conceptual dimensions of supply chain management: establishing a structural model. Global J. Manage. Bus. Res. $17,17-28$.

Sauvé, S., Bernard, S., and Sloan, P. (2016). Environmental sciences, sustainable development and circular economy: alternative concepts for transdisciplinary research. Environ. Dev. 17, 48-56. doi: 10.1016/j.envdev.2015. 09.002

SCOR (2012). Supply Chain Operations Refernce Model. Revision 11.0. Available online at: https://docs.huihoo.com/scm/supply-chain-operations-referencemodel-r11.0.pdf

Sehnem, S., Campos, L. M., Julkovski, D. J., and Cazella, C. F. (2019a). Circular business models: level of maturity. $M D$ 57, 1043-1066. doi: 10.1108/MD-07-2018-0844

Sehnem, S., Chiappetta Jabbour, C. J., Farias Pereira, S. C., and de Sousa Jabbour, A. B. L. (2019b). Improving sustainable supply chains performance through operational excellence: circular economy approach. Resources Conserv. Recycl. 149, 236-248. doi: 10.1016/j.resconrec.2019.05.021

Sehnem, S., Kuzma, E., Julkovsky, D. J., Frare, M. B., and Vazquez-Brust, D. (2021). Megatrends in circular economy: avenues for relevant advancements in organizations. Circ. Econ. Sust. 1, 173-208. doi: 10.1007/s43615-021-00036-x

Sehnem, S., Ndubisi, N. O., Preschlak, D., Bernardy, R. J., and Santos Junior, S. (2019c). Circular economy in the wine chain production: maturity, challenges, and lessons from an emerging economy perspective. Production Plann. Control 31, 1014-1034. doi: 10.1080/09537287.2019.1695914

Seong Leem, C., and Yoon, Y. (2004). A maturity model and an evaluation system of software customer satisfaction: the case of software companies in 
Korea. Industr. Manage. Data Syst. 104, 347-354. doi: 10.1108/026355704105 30757

Seuring, S., and Müller, M. (2008). From a literature review to a conceptual framework for sustainable supply chain management. J. Clean. Production 16, 1699-1710. doi: 10.1016/j.jclepro.2008.04.020

Siddi, M. (2020). The European Green Deal: Assessing Its Current State and Future Implementation. Helsinki: Finnish Institute of International Affairs.

Srai, J. S., Alinaghian, L. S., and Kirkwood, D. A. (2013). Understanding sustainable supply network capabilities of multinationals: a capability maturity model approach. Proc. Inst. Mech. Eng. Part B J. Eng. Manufac. 227, 595-615. doi: 10.1177/0954405412470597

Stahel, W. R. (2019). The Circular Economy: A User's Guide. London: Routledge.

Standing, C., and Jackson, P. (2007). An approach to sustainability for information systems. J. Syst. Info Tech 9, 167-176. doi: 10.1108/13287260710839247

Steven, M. (2019). Einführung in Die Produktionswirtschaft. Stuttgart: Verlag W. Kohlhammer.

Stevenson, A. (2010). The Oxford Dictionary of English. Oxford: Oxford University Press.

Stevenson, M., and Spring, M. (2007). Flexibility from a supply chain perspective: definition and review. Int. J. Op Prod. Manage. 27, 685-713. doi: 10.1108/01443570710756956

Tranfield, D., Denyer, D., and Smart, P. (2003). Towards a methodology for developing evidence-informed management knowledge by means of systematic review. Br. J. Manage. 14, 207-222. doi: 10.1111/1467-8551.00375

Umweltbundesamt (2018). Die Nutzung natürlicher Ressourcen - Bericht für Deutschland 2018. Available online at: https://www.umweltbundesamt.de/ sites/default/files/medien/3521/publikationen/deuress18_de_bericht_web_f. pdf (accessed August 15, 2021).

UN (2015). Paris Agreement. Available online at: https://unfccc.int/sites/default/ files/english_paris_agreement.pdf (accessed July 5, 2021).

Ünal, E., and Shao, J. (2019). A taxonomy of circular economy implementation strategies for manufacturing firms: analysis of 391 cradle-to-cradle products. $J$. Clean. Production 212, 754-765. doi: 10.1016/j.jclepro.2018.11.291

Vaidyanathan, K., and Howell, G. (2007). Construction supply chain maturity model - conceptual framework. Proc. IGLC 15, 170-180.

van Landeghem, R., and Persoons, K. (2001). Benchmarking of logistical operations based on a causal model. IJOPM 21, 254-267. doi: $10.1108 / 01443570110358576$
Vegter, D., van Hillegersberg, J., and Olthaar, M. (2020). Supply chains in circular business models: processes and performance objectives. Resources Conserv. Recycl. 162:105046. doi: 10.1016/j.resconrec.2020.105046

WCED (1987). Our Common Future. Available online at: http://www.undocuments.net/ocf-02.htm (accessed June 2, 2021).

Wendler, R. (2012). The maturity of maturity model research: a systematic mapping study. Information Softw. Technol. 54, 1317-1339. doi: 10.1016/j.infsof.2012.07.007

World Economic Forum (2021). Net-Zero Challenge: The Supply Chain Opportunity. Available online at: http://www3.weforum.org/docs/WEF_Net_ Zero_Challenge_The_Supply_Chain_Opportunity_2021.pdf (accessed August $15,2021)$.

Yadav, G., Mangla, S. K., Bhattacharya, A., and Luthra, S. (2020). Exploring indicators of circular economy adoption framework through a hybrid decision support approach. J. Clean. Production 277:124186. doi: 10.1016/j.jclepro.2020.124186

Zhao, D., Zhang, L., Liu, X., and Sun, J. (2006). "A new supply chain maturity model with 3-dimension perspective," in 2006 International Technology and Innovation Conference (ITIC 2006) (Hangzhou), 1732-1737.

Conflict of Interest: The authors declare that the research was conducted in the absence of any commercial or financial relationships that could be construed as a potential conflict of interest.

Publisher's Note: All claims expressed in this article are solely those of the authors and do not necessarily represent those of their affiliated organizations, or those of the publisher, the editors and the reviewers. Any product that may be evaluated in this article, or claim that may be made by its manufacturer, is not guaranteed or endorsed by the publisher.

Copyright (๑) 2021 Montag, Klünder and Steven. This is an open-access article distributed under the terms of the Creative Commons Attribution License (CC BY). The use, distribution or reproduction in other forums is permitted, provided the original author(s) and the copyright owner(s) are credited and that the original publication in this journal is cited, in accordance with accepted academic practice. No use, distribution or reproduction is permitted which does not comply with these terms. 